\title{
Social attitudes, intelligibility and comprehensibility: The role of the listener in the perception of non-native speech
}

\author{
Ellen Simon \\ Department of Linguistics \\ Ghent University, Belgium \\ Ellen.Simon@UGent.be \\ Chloé Lybaert \\ Department of Translation, Interpreting and Communication \\ Ghent University, Belgium \\ Chloe.Lybaert@UGent.be \\ Koen Plevoets \\ Department of Translation, Interpreting and Communication \\ Ghent University, Belgium \\ Koen.Plevoets@UGent.be
}

\begin{abstract}
This study investigates the role of the listener in the perception of non-native speakers and their speech. Our goal is to examine the impact of listener characteristics on their attitudes towards non-native speakers and their speech. In addition, we aim to explore the relationship between listeners' attitudes and the intelligibility, comprehensibility and perceived foreign accentedness of non-native speech. 126 participants living in Flanders, Belgium, completed a questionnaire probing their attitudes towards non-native speakers of Dutch. An analysis of background variables of these listeners revealed that their age, educational level, extent of contact with nonnative speakers and especially political preference could predict their responses to questionnaire items. In a subsequent session, participants performed (a) a speaker/ speech evaluation task, (b) a transcription task measuring intelligibility, and (c) a comprehensibility and accentedness rating task. This latter session required participants to transcribe and evaluate speech samples of Dutch produced by speakers of Mandarin Chinese. We found a significant correlation between comprehensibility and accentedness and a number of attitudinal dimensions, such as the perceived status of, and solidarity with, the speaker. The study has implications for language testing, as it demonstrates the impact of listeners' social attitudes on the assessment of nonnative speech.
\end{abstract}


Keywords: Intelligibility; comprehensibility; social attitudes; non-native speech: foreign accent.

\section{Abstract}

Diese Studie untersucht die Rolle des Zuhörers bei der Wahrnehmung von NichtMuttersprachlern und ihrer Rede. Wir wollten den Einfluss von Zuhörermerkmalen auf die Einstellung der Zuhörer gegenüber Nicht-Muttersprachlern und NichtMuttersprachlern untersuchen und die Beziehung zwischen der Einstellung der Zuhörer und der Verständlichkeit ("intelligibility" sowie "comprehensibility") und wahrgenommenen Fremdsprachenakzentuierung von Nicht-Muttersprachlern untersuchen. Insgesamt 126 Teilnehmer in Flandern, Belgien, füllten einen Fragebogen aus, der ihre Einstellung gegenüber Nicht-Muttersprachlern untersuchte. Eine Analyse der Hintergrundvariablen dieser Zuhörer ergab, dass ihr Alter, ihr Bildungsniveau, das Ausmaß des Kontakts mit Nicht-Muttersprachlern und insbesondere ihre politischen Präferenzen ihre Antworten auf die Fragen des Fragebogens vorhersagen konnten. In einer anschließenden Sitzung führten die Teilnehmer (a) ein Sprecher/ Sprache-Evaluierungsexperiment, (b) eine Transkriptionsaufgabe zur Messung der Verständlichkeit und (c) eine Begreifbarkeits- und Akzentuierungsbewertung durch, bei der Sprechproben ausgewertet wurden, die von niederländischsprachigen Zweitsprachlern des Mandarin-Chinesischen erstellt worden waren. Wir fanden eine signifikante Korrelation zwischen Verständlichkeit und Akzentuierung und einer Reihe von Einstellungsdimensionen, wie z.B. dem wahrgenommenen Status des Sprechers und der Solidarität mit ihm. Die Studie hat potentielle Auswirkungen auf Sprachtests, da sie den Einfluss der sozialen Einstellungen der Zuhörer auf die Beurteilung von Nicht-Muttersprachlern.

Keywords:Verständlichkei; Begreifbarkeit; soziale Einstellunge; NichtMuttersprachler; ausländischer Akzent.

\section{Introduction}

It is commonly known that non-native speech typically contains acoustic-phonetic properties that deviate from average native speech properties. In fact, late learners, broadly defined as those who learn a non-native language well after childhood, are rarely indistinguishable from those who have acquired the language from birth (exceptions are reported in Bongaerts, Mennen \& van der Slik, 2000). This is the result of cross-linguistic interaction, the process through which speakers transfer phonetic and phonological properties, both segmental and prosodic, from their 
native language into the target language and vice versa (Major, 2001). Cross-linguistic interaction is the central concept in second language speech and perception models, such as the Speech Learning Model (Flege, 1995) and the Perceptual Assimilation Model (Best, 1995; Best \& Tyler, 2007). More specifically, a growing number of studies have shown that acquiring phonological properties of a non-native language which are not contrastive in the native language remains problematic, even for advanced learners, and this holds for both production and perception (see Bohn \& Munro, 2007, for an overview). Awareness of these findings, as well as the gradual realization that the concept of the native speaker is problematic in many contexts (cf. the growing recognition of World Englishes and the related issue of ownership, Davies, 2013), have led to a shift of pronunciation goals in foreign language learning. The goal of a native-like pronunciation, based on the model of the native speaker as the ultimate target, has gradually been replaced by the goal of fluent communication and mutual intelligibility (Jenkins, 2000; 2005; Levis \& LeVelle, 2010).

In line with this shift, oral proficiency targets in foreign language learning are now increasingly expressed in terms of intelligibility. Examples can be found in the descriptions of proficiency levels in the Common European Framework of Reference for Languages (CEFR; Council of Europe, 2001), where the extent to which learners are intelligible to interlocutors plays a key role in the descriptions of the proficiency scales (Beinhoff, 2014). Intelligibility is, however, a concept that cannot easily be defined, because it is the result of an intricate interplay between different factors related not only to the speaker but also-crucially-to the listener (see Section 2.1). There is, indeed, growing awareness of the role of the listener in studies on intelligibility. It is now generally acknowledged that the extent to which a speaker is intelligible to the interlocutor is ultimately not only determined by the speaker's pronunciation and lexicogrammar but also by characteristics of the listener. It is this role of the listener that is the focus of the present study. In particular, we examine the impact of listener characteristics on the formation of social attitudes towards non-native speakers and their speech. The aim is to find out whether listeners' characteristics can predict social attitudes towards non-native speakers and non-native speech and whether listeners' evaluations can predict the intelligibility, comprehensibility and (foreign) accentedness of non-native speech (see Section 3).

Section 2 contains a literature review. We first focus on the differences and similarities between three related constructs: "intelligibility", "comprehensibility" and "accentedness". We briefly explain how these constructs have been defined in earlier research and which definitions we use in the present paper (Section 2.1). We then look at the role of the listener in earlier research on intelligibility and comprehensibility of non-native speech (Section 2.2). The specific research questions in our own empirical 
study are discussed in Section 3. We describe the methodology in Section 4 and the results in Section 5. Section 6 contains the discussion. Conclusions and suggestions for further research are presented in Section 7.

\section{Review of the Literature}

\subsection{Intelligibility, comprehensibility and accentedness: terminology and measurement}

In the present study, we follow Munro \& Derwing (1995a) in their identification of three separate but related constructs: "intelligibility", "comprehensibility" and "accentedness". Munro \& Derwing (1995a) distinguish between "intelligibility", which they define as the extent to which actual speech units are recognized by the listener, and "(perceived) comprehensibility", which refers to the extent to which speech is reported to be understood by the listener. The two main linguistic dimensions that have been shown to influence a speaker's intelligibility and comprehensibility are pronunciation (segmental properties, prosody and fluency) and lexicogrammar (richness of vocabulary as well as accuracy and complexity of grammar) (Saito, Trofimovich \& Isaacs, 2017). Although intelligibility and comprehensibility are related in the sense that speech which is highly intelligible is also generally rated high for comprehensibility, Munro \& Derwing (1995a, b) and Derwing \& Munro (1997) showed that the two constructs are also partially independent of each other. Surprisingly, it appeared to be the case that a number of speakers who were almost perfectly intelligible to some listeners (as shown by their near perfect transcription scores) were not rated as highly comprehensible by these same listeners. Intelligibility and comprehensibility are often discussed in relation to a third concept, that of (foreign or non-native) "accentedness". Gallardo del Puerto, García Lecumberri \& Gómez Lacabex (2015) define a foreign accent as "the pronunciation of a language which presents phonological features that deviate from native phonological usage" (p. 203). Accentedness, as a characteristic of non-native speech, is closely related to intelligibility, as it presents a deviation from listeners' expectations and hence a potentially adverse condition for optimal speech perception (Mattys et al., 2012). However, it is also closely linked to comprehensibility, in that the extent to which speech is judged to be ("foreign") accented is a matter of the listener's reported perception.

Since intelligibility refers to the actual recognition of specific units of speech (Kachru \& Smith, 2008), whereas comprehensibility and accentedness refer to listeners' reported perceptions, the way in which these constructs are measured is different. Measures of intelligibility focus on the extent to which listeners are able to 
correctly identify words or speech sounds targeted by the speaker. Kent \& Miolo (1994) review several procedures that have been used in previous studies to measure speech intelligibility in children who are likely to be diagnosed with a speech disorder. These procedures include, for instance, attesting the percentage of correctly recognized target words, or more specifically consonants or vowels (embedded in consonantal frames, as in e.g. feel-fill-fall-fell). Such methods are similar to those used in studies on multilingual speakers or second language learners. Kang, Thomson \& Moran (2018) compare five intelligibility measures in different varieties of non-native speech, in order to determine the efficacy of these measures in predicting listening comprehension scores. Measures included responses to true/false statements, scalar ratings of speech, perception of nonsense sentences, perception of filtered sentences, and transcription of speech. The measures differed in the amount and type of context that the listener received. Results revealed that the relationship between the five measures was weak, suggesting that they tap into slightly different constructs. The measure that best predicted listener comprehension of longer speech samples of the same speakers was a transcription task. This task required listeners to transcribe missing words in grammatically correct, but semantically nonsensical sentences, such as "The tall kiss can draw with an oak". The advantage of using nonsensical sentences over semantically meaningful sentences lies in the absence of context which would enable listeners to guess the missing words. As Kang et al. (2018: 119) point out, the technique was developed for speech technology and audiology and was later adapted for use in studies on speech intelligibility (e.g. Bent \& Bradlow, 2003).

As pointed out above, comprehensibility and foreign accentedness are different from intelligibility, in that they reflect listeners' reports on, respectively, the extent to which they understand the speaker and the extent to which the speech deviates from what they view as a native language accent. Comprehensibility and foreign accentedness are therefore typically measured through rating scales, in which listeners are asked to indicate the degree of comprehensibility and the strength of the foreign accent (cf. e.g. Munro \& Derwing, 1995a; Munro, 2008).

\subsection{The role of listener characteristics in intelligibility research}

As noted in the Introduction, the role of the listener is increasingly recognised as crucial in studies on intelligibility, comprehensibility and accentedness. It is now generally acknowledged that the extent to which a speaker will be intelligible to the interlocutor will ultimately be determined not only by the speaker's pronunciation and lexicogrammar but also by characteristics of the listener. Rajaduraj (2007) refers to Morley (1991), who claims that "intelligibility may be as much in the mind of the listener as in the mouth of the speaker" (p. 499). A recent and comprehensive 
study by Saito et al. (2019) examines how comprehensibility and foreign accentedness judgements are affected by listener characteristics, including the listener's first language (L1), level of proficiency in the second language (L2), age, experience, familiarity and metacognition. They compared responses to listener background questionnaires by 120 respondents (110 L2 listeners and $10 \mathrm{~L} 1$ listeners) with comprehensibility ratings of 50 speakers. The results showed that metacognition (level of awareness of the importance of "comprehensible" pronunciation and lexicogrammar), experience (extent of contact with L2 speakers) and L1-L2 distance predicted listeners' comprehensibility scores assigned to the L2 speakers. The effect of the listener's native language on L2 speech intelligibility was also studied, and Bent \& Bradlow (2003) observed an "interlanguage speech intelligibility benefit" (ISIB). This means that non-native listeners were as accurate in recognizing words produced by a high-proficiency non-native speaker with whom they shared the native language as they were in recognizing words produced by a native speaker (cf. also Hayes-Harb, Smith, Bent \& Bradlow, 2008). Winke, Gass \& Myford (2013) examined the effect of accent familiarity, defined as the result of having studied the speaker's L1. For example, native English speakers who had studied Korean were considered to be familiar with a Korean accent in English. By examining comprehensibility and speech ratings of 107 listeners judging speech samples produced by 72 test takers, they found that the linguistic background of listeners should indeed be taken into account as a potential rater effect.

Besides listener characteristics such as his or her first language, accent familiarity and the extent of contact with L2 speakers, another aspect of listeners' profiles that has been put forward in intelligibility and comprehensibility research relates to listeners' social attitudes (see Kennedy \& Trofimovich, 2019, for a recent discussion on social influences on comprehensibility). We define social attitudes as listeners' attitudes towards social stimuli, in this case non-native speakers and non-native speech. Rajadurai claims that while positive attitudes towards speakers and accents may enhance intelligibility and facilitate communication, listeners' biases or negative judgements may act as barriers to intelligibility (2007: 90). This claim is supported by a set of previous studies, some dating back to the ' 80 s and ' 90 s, but others just recently published (Babel \& Russell, 2015; Eisenstein \& Verdi, 1985; Lindeman, 2002; Rubin, 1992; Sheppard, Elliott \& Baese-Berk, 2017; Taylor Reid, Trofimovich \& O’Brien, 2019). These studies have shown that listeners' attitudes towards, and evaluations of, certain accents can be associated with intelligibility and/or comprehensibility. The studies widely differ in the methodological choices they make with respect to the type of task and stimuli and the precise nature of the construct they measure, ranging from intelligibility (e.g. Babel \& Russell, 2015) over comprehensibility (e.g. Taylor Reid et al., 2019) to, more generally, perceived success of the interaction (e.g. Lindeman, 2002). 
Babel \& Russell (2015), for instance, showed that speech intelligibility decreased when listeners were shown a picture of an ethnically Chinese Canadian speaker compared to when no visual prime was presented. This effect was not found for White Canadian speakers, suggesting that listeners associate Chinese faces with less intelligible, non-native accents.

Taylor Reid, Trofimovich \& O'Brien (2019) manipulated listeners' social biases before they were asked to evaluate second language speech. Listeners who were positively oriented towards Quebec French speakers of L2 English by hearing positive comments about them rated their comprehensibility more favourably than baseline listeners, who had not been presented with any comments. Negatively biased listeners showed divergent patterns of ratings: while negatively oriented younger listeners rated the speakers' comprehensibility more favourably, older negatively oriented listeners downgraded the speakers compared to the baseline group. The authors surmise that positively oriented listeners and younger negatively oriented listeners may have experienced enhanced solidarity with the L2 speakers (e.g. by drawing parallels to themselves when speaking an L2), while older negatively oriented listeners may have perceived a large social distance between themselves and the speakers (Taylor Reid et al., 2019: 434).

Finally, Lindeman (2002) examined whether native English speakers who were assessed as having either positive or negative attitudes towards Koreans performed differently on an interactional map task with native Korean speakers of English as L2. She found that some of the speakers with negative attitudes used strategies problematizing their interlocutor's utterances or avoidance strategies (e.g. not asking additional questions). Lindeman also found a direct relationship between attitudes and perceived success of the interaction, with more positive attitudes correlating with the perception of a higher success level.

In sum, although previous studies of the effect of listeners' social attitudes on how non-native speakers and their speech are perceived, have adopted different approaches and methods, there is a growing body of research suggesting that listeners' attitudes indeed impact on L2 speech perception and assessment and that they should therefore be taken into account in research on L2 intelligibility and comprehensibility. The question then arises as to which factors influence these attitudes. The literature on this topic mostly deals with large sets of respondents' background characteristics shaping their attitudes towards immigrants or refugees in general (e.g. Chandler \& Tsai, 2001; Butkus, Maciulyte-Sniukiene \& Matuzeviciute, 2016; Murray \& Marx, 2013). The studies do not focus specifically on attitudes to non-native speakers and their speech. The respondents' background characteristics "age", "level of education", "extent of contact with the target population" and "political preference" are among the variables most often studied. 
Butkus et al. (2016) review the literature on factors shaping attitudes towards immigrants and refugees and conclude that "in general, most positive and tolerant attitudes are associated with youth, high socio-economic status, high educational attainment and left-wing political sympathies" (Hainmueller \& Hiscox, 2007). These factors are originally discussed in sociological theories, such as Human Capital Theory, which analyses the effect of education on attitudes. The general claim is that people with a higher level of education are more tolerant towards immigrants and refugees, because there is no economic competition with that group, whose members are often unskilled or semi-skilled (Mayda, 2006, in Butkus et al., 2016). Moreover, as pointed out by Chandler and Tsai (2001), people who have enjoyed a higher level of education tend to have more diverse and cosmopolitan networks, fostering tolerance. According to the Contact Theory, people who have closer contact with the target population have more positive attitudes to immigrants, since people are generally prejudiced towards things they do not know (Butkus et al., 2016: 287). Political preference is generally thought to be linked to attitudes towards migration in the sense that people with right-wing or conservative political ideologies tend to take a more negative stance towards immigrants (Chandler \& Tsai, 2001; but see also Murray \& Marx, 2013, who did not find an effect of political orientation). Finally, age is one of the demographic variables of respondents that is generally believed to have an effect on people's attitudes towards migration. Card, Dustman \& Preston (2005) argue that there are several reasons for this. One explanation is that age marks the position of the individual in their economic cycle. For instance, people who are active on the labour market may show attitudes towards immigrants that are different from those of adolescents who do not yet need to compete for jobs. A large-scale survey of attitudes towards immigration in Europe showed that, if educational level is held constant, older people generally had stronger anti-immigrant views (Card, Dustman \& Preston, 2005). The authors note that this difference between younger and older respondents may be the result of aging or of a difference between birth cohorts. In other words, it is possible that, as an individual gets older, they develop more negative attitudes towards immigrants, but it is also possible that people who grew up in, for instance, the 1940s developed less liberal attitudes towards immigration than people who grew up in the 1980s and kept these attitudes throughout their lives (Card, Dustman \& Preston, 2005: 26). Further research is needed to tease out these factors.

\section{The study}

\subsection{Aims and research questions}

The goal of the present study was to examine the impact of listener characteristics on listeners' attitudes towards non-native speakers and non-native speech and to explore 
the relationship between listeners' attitudes and the intelligibility, comprehensibility and perceived foreign accentedness of non-native speech. To this end, we set up experimental research in which native Dutch speakers first completed a background and attitudinal questionnaire. In a second session they were given a transcription task, a speaker/speech evaluation task and were asked to rate the comprehensibility and accentedness of L2 Dutch speech samples by native speakers of Mandarin Chinese. We opted for native speakers of Chinese because we wanted to use speech produced by speakers with a native language that is not related to Dutch (Dutch belongs to the Indo-European language family, while Chinese is part of the Sino-Tibetan language family) and hence possibly less intelligible than speech produced by speakers of a language closely related to Dutch (cf. also Caspers \& Horloza, 2012).

We address the following two research questions:

1. Can listeners' characteristics (age, level of education, extent of contact with L2 speakers, political ideology) predict social attitudes towards non-native speakers and non-native speech?

2. Can listeners' evaluations of non-native speakers and non-native speech predict the intelligibility, comprehensibility and (foreign) accentedness of non-native speakers and non-native speech?

On the basis of the literature reviewed in Section 2.2., our hypothesis is that all four listener characteristics examined-age, level of education, extent of contact with L2 speakers and political ideology-will, to some extent, predict listeners' attitudes towards non-native speakers and non-native accents, as measured through listeners' responses in a questionnaire. Specifically, we predict that more lenient attitudes will be associated with younger respondents, respondents with a higher educational level, more contact with non-native speakers and with a preference for a more left-wing political ideology. By more lenient attitudes towards non-native speakers and their speech we mean, for instance, more patience with newcomers who have to learn Dutch, more positive expectations about conversations with non-native speakers and more tolerant attitudes towards non-native accented speech.

With respect to listeners' attitudes, as reflected in a non-native speaker evaluation experiment, our expectations are less pronounced, as previous studies addressing this issue have involved a variety of tasks and procedures. While we expect to find an association between listeners' evaluations of non-native speakers and speech on the one hand, and the intelligibility, comprehensibility and (foreign) accentedness scores of these listeners on the other, the effect is possibly a subtle one. 
The study was carried out in Belgium, where Dutch, French and German are the three official languages, spoken in different regions of the country, with Brussels being officially bilingual in French and Dutch. The research was conducted in Flanders, the northern part of Belgium, where Dutch is the native language of the majority of the inhabitants, but where a multitude of other languages are used as home languages, as a result of migration. Most migrants have EU-nationalities, with migrants from Morocco, Syria and India as exceptions in the top 10 nationalities of migrants in 2016. In the list of non-EU-nationalities of international migrants in 2016, Chinese takes fifth position (see Section 3.2.2.2) (Noppe et al., 2018). Semyonov, Raijman \& Gorofzeisky (2006) report fairly average levels of ethnic diversity and anti-immigrant sentiments in Belgium compared to 11 other Western European countries in the period 1988-2000. A 2017 survey by the Flemish government probing the beliefs and attitudes of the Dutch-speaking population in Flanders and Brussels revealed that more than half of the sample population believed that the presence of other cultures enriches society. By contrast, $14 \%$ of the population reported not to trust migrants and 30\% believed that migrants are a threat to the Flemish culture and values (Noppe et al., 2018). Although our study focuses on non-native speakers instead of migrants, we predict that the same positive and negative attitudes reflected in these survey results will be echoed in our study.

\subsection{Methodology}

Our study consisted of two main parts, for which data were collected at two different times. An interval of two to three months between the two data collection points was opted for, because we wanted to prevent participants from being influenced by their answers in the first part (attitudes towards non-native speakers and their speech in general) when completing the second part (including a speaker evaluation task). We therefore describe the methodology of the two parts in separate sections (Section 3.2.1 and Section 3.2.2).

\subsubsection{Part 1}

For part 1, we designed a questionnaire with statements about non-native speakers and non-native speech.

\subsubsection{Materials}

The questionnaire was meant to probe participants' attitudes towards non-native speakers and non-native speech in general, i.e. not restricted to non-native speakers 
or speech from a specific linguistic background. In order to do so, we designed 34 statements, covering nine themes: (1) attitudes towards learning Dutch, (2) political ideology, (3) view on second language acquisition processes, (4) willingness to put in extra effort when communicating with L2 speakers, (5) comprehensibility of L2 speakers, attitudes towards L2 speakers and their speech related to (6) status, (7) solidarity, and (8) aesthetic value (i.e., how beautiful a language is considered to be or how pleasant it is thought to sound), and (9) attitudes towards variation in language.

The statements were designed by the authors, but inspired by previous studies probing social attitudes towards language varieties and their speakers (Latour et al., 2012; Grondelaers \& Speelman, 2013; Delarue, 2016; Lybaert, 2017). Nine themes were selected for which, on the basis of the literature, we had reason to believe they would be related to intelligibility and comprehensibility/accentedness of non-native speakers. Attitudes towards L2 speakers regarding status, solidarity and aesthetic value, for instance, are dimensions which are typically addressed in speaker evaluation experiments because they have been shown to be relevant factors (see e.g. Latour et al., 2012; Grondelaers \& Speelman, 2013). "Attitudes towards variation in language" was included as a theme because attitudes towards non-standard variation have been the subject of much discussion in the Dutch-speaking area (e.g. Lybaert, 2017; Delarue, 2016) and we hypothesized that there may be a link between people's attitudes towards endogenous and exogenous varieties of Dutch. The theme "political ideology" was included because previous studies (reviewed in Section 2.2) claim that political sympathies are associated with attitudes towards immigrants and these, in turn, may affect intelligibility or comprehensibility of non-native speech. "Attitudes towards learning Dutch", "view on second language acquisition processes", "willingness to put in extra effort when communicating with L2 speakers" and "comprehensibility of L2 speaker" were not directly based on previous studies, but fitted our goal of probing participants' general beliefs about language acquisition and their stance towards conversations with non-native speakers. All statements are included in Section 4.1, Table 2.

Participants were asked to indicate on five-point Likert scales to what extent they agreed or disagreed with each statement ( $1=$ strongly disagree, $2=$ somewhat disagree, $3=$ neutral, $4=$ somewhat agree, $5=$ strongly agree). None of the statements contained negations. Half of the statements $(\mathrm{N}=17)$ were formulated in a way that agreeing would reflect a fairly positive attitude (e.g. "I feel safe with non-native speakers of Dutch"), while agreement with the remaining half would be a sign of a rather negative attitude (e.g. "Speaking with a non-native speaker of Dutch often leads to misunderstandings").

At the end of the questionnaire, we also collected some background information: we included questions about the participants' age, gender, the place where they had 
spent most of their childhood, and the highest qualification obtained. Participants were also asked about their political preference through a multiple-choice question with the options "far left", "left-of-centre", "centre", "right-of-centre" and "far right". To conclude, they were asked how much contact they have with non-native speakers of Dutch (rarely or never, on a monthly, weekly or daily basis). In this paper, we focus on the impact of the background variables "age", "highest qualification obtained", "political preference" and "contact with non-native speakers" on the attitudes of the respondents.

\subsubsection{Procedure}

The questionnaire was presented and completed through an online platform. Participants were instructed to complete the questionnaire on a PC or laptop, since we believed that completing a longer questionnaire on a smartphone might lead to concentration loss. The questionnaires were processed anonymously, and participants were invited to answer as honestly as possible. All participants were informed on their right to withdraw their answers at any point and on the anonymization of the data. They all completed an informed consent form.

\subsubsection{Participants}

A total of 126 respondents completed the questionnaire in Part 1 . They were recruited from the researchers' social networks through social media. Only participants aged between 18 and 50 were encouraged to participate.

Responses to background questions in the questionnaire (cf. 3.1.2) revealed the following participant characteristics: the respondents' ages ranged between 18 and 50 , with a mean age of 31 . Of those respondents, 49 were male and 77 were female. They had spent most of their childhood in the regions East- and West-Flanders and Flemish Brabant (East-Flanders $=89$, West-Flanders=17, Flemish Brabant=17). Only three participants came from the provinces of Antwerp $(\mathrm{N}=2)$ and Limburg $(\mathrm{N}=1)$.

The highest qualifications obtained were a diploma in secondary education (vocational schooling $(\mathrm{N}=3)$, technical schooling $(\mathrm{N}=18)$ or general schooling $(\mathrm{N}=31)$ ), a Bachelor's degree $(\mathrm{N}=56)$, a Master's or PhD degree $(\mathrm{N}=20)$. It should be noted that 37 participants were still studying and hence working towards a Bachelor's or Master's degree.

We observed the following distribution in the participants' political preference: far left $(\mathrm{N}=1)$, left-of-centre $(\mathrm{N}=21)$, centre $(\mathrm{N}=59)$, right-of-centre $(\mathrm{N}=44)$ and far 
right $(\mathrm{N}=1)$. As only one respondent answered with "far right" and only one with "far left", these answers were added to the categories "right-of-centre" and "left-of-centre", respectively. When asked how much contact they had with non-native speakers of Dutch, the participants responded "rarely or never" $(\mathrm{N}=11)$, "monthly" $(\mathrm{N}=36)$, "weekly" (N=50) and "daily" (N=29).

\subsubsection{Part 2}

For the second part of the study, we used recorded speech samples from two nonnative speakers. This second part of the study consisted of three tasks: a transcription task, a comprehensibility and accentedness judgement task, and a speaker/speech evaluation task. All tasks were offered to participants in LimeSurvey Version 2.73.1.

\subsubsection{Participants}

All participants of Part $1(\mathrm{~N}=126)$ were also invited to participate in Part 2 of the study, two to three months after the data for Part 1 were collected. In total, 102 participants took part in the second part of the study. The remaining 24 participants did not react to the call for the second part of the study.

\subsubsection{Speech stimuli}

The second part of the study contained recorded speech samples from two nonnative speakers of Dutch, henceforth referred to as speakers A and B. The speakers were selected for their very similar profiles: they were both female native speakers of Mandarin Chinese, who were born and raised in China, but moved to Belgium (in the area of Ghent) as adults. Both speakers have a Master's degree in Marketing (obtained in Belgium) and a native Dutch-speaking partner, with whom they (mainly) communicate in English. At the time of the recording, they had both reached CEFR proficiency level C1 in Dutch at the same centre for adult education in Ghent and were selected by their Dutch teacher as motivated learners. When asked whether interlocutors have difficulties understanding them when they speak Dutch, they both selected the answer "sometimes" (from the options "never", "rarely", "sometimes", "often" and "very often"). We opted for participants with a high proficiency level in Dutch, because we wanted to obtain information on the perception of L2 speakers who could perfectly express themselves in Dutch, but had a noticeable accent. Speech samples from two speakers were selected because we wanted to examine potential individual differences between two speakers with similar language profiles. We held the view that including more speakers for all three tasks would make the experiment 
unnecessarily long, potentially leading to concentration loss on the part of the listeners.

Speaker A was 30 years old at the time of the recording and moved to Belgium seven years ago (age 23), when she started taking Dutch classes. She describes her Dutch as "quite good". Speaker B was 37 years old at the time of the recording. She moved to Belgium 13 years ago (age 24) but spent a total of four years in New York and Shanghai between her arrival in Belgium and the time of the recording. She perceives here own proficiency in Dutch as "average". The recordings were made in a sound-attenuated room. They consisted of three tasks: for task 1, informants read aloud 48 sentences; for task 2 they were asked to tell us something about the holiday of their dreams and for task 3 they read aloud a small text. They were given a few minutes to prepare this last task. The total time of the recording session was 45-60 minutes per person.

\subsubsection{Tasks and materials}

\subsection{Transcription task}

All participants completed a transcription task. This task contained a selection of 24 unique and grammatically correct Dutch sentences, 12 of which were produced by speaker $A$ and 12 by speaker B. Each speaker had produced 6 semantically meaningful sentences and 6 nonsensical sentences. The audio sentences were presented together with their orthographic transcriptions, in which one target word was left out from every sentence. Participants were instructed to listen to the sentences and transcribe the missing words. Nonsensical sentences were included in order to avoid participants guessing from the semantic context which word was missing (cf. Kang et al., 2018; see Section 2.1). The missing target words contained six vowels, forming three vowel contrasts: $/ \mathrm{i} / / \mathrm{l} /, / \mathrm{e} /-/ \varepsilon /$ and $/ \mathrm{a} / / \mathrm{a} /$. Half of the missing words were nouns, the other half were verbs (see Appendix 1 for an overview of the selected sentences).

Table 1. Missing target words transcription task

\begin{tabular}{llllllll}
\hline & & i & I & e & $\varepsilon$ & a & a \\
\hline Speaker 1 & nonsensical & piekt & pikt & heeft & heft & kaas & Kat \\
\hline & semantically meaningful & biedt & bidt & peer & step & raad & Rat \\
\hline Speaker 2 & nonsensical & ziet & zit & zeep & schep & zaak & Zak \\
\hline & semantically meaningful & stier & schip & veegt & vecht & kaapt & Kapt \\
\hline
\end{tabular}


The respondents first had to transcribe the missing words in the semantically meaningful sentences: after two test sentences, the actual 12 semantically meaningful sentences of the two speakers were presented in random order. The respondents were given the instruction to write the word they heard under the sentence. If they really did not understand the word, they had to type "not understood". After filling in the missing words in the semantically meaningful sentences, the respondents were presented with the nonsensical sentences. Again, they were presented with two warmup sentences first, followed by the actual 12 nonsensical sentences in random order.

\subsection{Comprehensibility and accentedness judgement task}

The second part of the test consisted of a comprehensibility and accentedness judgement task. In this task, participants were presented with an audio file of semispontaneous speech (of approximately 15 seconds; an orthographic transcription is included in Appendix 2) by each speaker (see Section 3.2.2.2). The order of the two speakers was randomized across participants. After each presentation of an audio file, they were asked to indicate on a five-point Likert scale to what extent they agreed with the statement "I think this person is easily intelligible" (Ik vind deze persoon goed verstaanbaar) and to select an answer to the question "How do you rate the non-native accent of this speaker?" (Hoe sterk vind je het buitenlandse accent van deze persoon?) from 1 ("no accent") to 5 ("very strong accent").

\subsection{Speaker/speech evaluation task}

The third task in Part 2 was a speaker/speech evaluation task. Participants were asked to listen to two identical excerpts of read speech (of approximately 20 seconds), a short narrative text, once produced by speaker A and once by speaker B (an orthographic transcription is included in Appendix 3). They were subsequently asked to indicate the extent of their (dis)agreement with 17 statements on the speech/speaker they had just heard. The 17 statements covered five themes: (1) aesthetic value of the speech, (2) status of the speaker, (3) solidarity with the speaker, (4) comprehensibility of the speaker and (5) perceived level of integration of the speaker in society. The statements were selected on the basis of existing speaker evaluation experiments (see e.g. Grondelaers \& Speelman, 2013; Grondelaers \& Van Gent, 2019). The order of both fragments was again randomized across participants (an overview of the statements is given in Section 4.1, Table 2). 


\subsubsection{Analysis}

The 34 questions of Part 1 were first analysed with Principal Component Analysis in order to explore whether they could be grouped into broader categories, for example, according to the nine themes represented in the questionnaire. To this end, the 16 reversely coded questions were back-transformed, in order to align with the 18 other questions. However, many questions from different themes appeared to be correlated with each other. As a consequence, we decided not to work with principal components nor the nine underlying themes. Instead we analysed each of the 34 questions separately in a linear model with the six background variables as predictors (main effects). The results are presented in Section 4.1.

For the experiment in Part 2, the (102) respondents had to evaluate two speakers, so we fitted three Linear Mixed-effects Models with a random intercept for each of the respondents. The response variables were comprehensibility, intelligibility and foreign accent. The predictor variables were speaker (i.e. speaker A vs. B), context (i.e. meaningful sentences vs. nonsensical sentences) and the two-way interaction between speaker and context. In these Linear Mixed-effects Models, the attitudinal dimensions resulting from the 17 questions in task 3 were also added as predictor variables. These attitudinal dimensions were obtained with Principal Component Analysis. The results of both the Principal Component Analysis and the Linear Mixed-effects Models are shown in Section 4.2.

\section{Results}

\subsection{Listeners' characteristics vs. general attitudes towards non-native speakers/speech}

To answer our first research question (RQ1) we examined whether listeners' characteristics can predict their general attitudes towards non-native speakers and speech. We focus on the impact of the background variables "age", "educational level", "extent of contact with L2 speakers" and "political preference" on the responses to the set of statements about non-native speakers and speech.

Before we elaborate on the correlation between these background variables and the answers to the statements about non-native speakers and speech, we give an overview of (an English translation of) these statements. We calculated the mean, standard deviation, and median of the answers to these statements, and give an overview of the number of respondents (out of a total of 126) who answered with 
"strongly disagree", "somewhat disagree", "neutral", "somewhat agree" and "strongly agree". These descriptive statistics are referred to below, when we discuss the link between listener's characteristics and their attitudes.

Table 2. Descriptive general attitudes towards non-native speakers/speech

\begin{tabular}{|c|c|c|c|c|c|c|c|c|c|}
\hline & $\begin{array}{l}\text { Statement in } \\
\text { English }\end{array}$ & $\sum_{\Sigma}^{\tilde{\Xi}}$ & 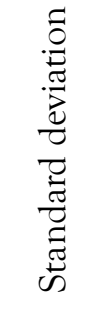 & 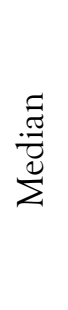 & 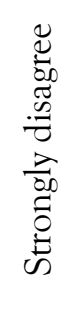 & 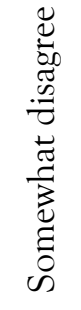 & $\begin{array}{l}\bar{\Xi} \\
\bar{\Xi} \\
\bar{Z}\end{array}$ & 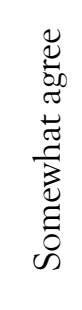 & 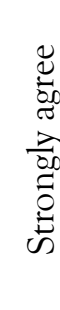 \\
\hline LEARN_1 & $\begin{array}{l}\text { Newcomers who } \\
\text { want to continue } \\
\text { living in Flanders } \\
\text { have to learn } \\
\text { Dutch. }\end{array}$ & 4.46 & 0.59 & 5 & 0 & 0 & 6 & 56 & 64 \\
\hline LEARN_2 & $\begin{array}{l}\text { I feel annoyed } \\
\text { when migrants } \\
\text { have not learnt } \\
\text { Dutch after being } \\
\text { in Flanders for } \\
\text { many years. }\end{array}$ & 4.05 & 0.94 & 3 & 2 & 9 & 13 & 59 & 43 \\
\hline LEARN_3 & $\begin{array}{l}\text { Many non-native } \\
\text { speakers make } \\
\text { an effort to learn } \\
\text { Dutch. }\end{array}$ & 3.31 & 0.98 & 4 & 3 & 25 & 41 & 44 & 13 \\
\hline POL_1 & $\begin{array}{l}\text { There are too many } \\
\text { non-native speakers } \\
\text { in Flanders. }\end{array}$ & 2.98 & 1.04 & 3 & 10 & 29 & 51 & 26 & 10 \\
\hline POL_2 & $\begin{array}{l}\text { I believe the } \\
\text { government spends } \\
\text { too much money } \\
\text { on Dutch language } \\
\text { classes for non- } \\
\text { native speakers. }\end{array}$ & 2.41 & 0.87 & 2 & 17 & 54 & 42 & 12 & 1 \\
\hline
\end{tabular}




\begin{tabular}{|c|c|c|c|c|c|c|c|c|c|}
\hline POL_3 & $\begin{array}{l}\text { I think it is } \\
\text { right that the } \\
\text { government spends } \\
\text { a lot of money } \\
\text { on Dutch classes } \\
\text { for non-native } \\
\text { speakers. }\end{array}$ & 3.72 & 0.89 & 4 & 1 & 12 & 30 & 61 & 22 \\
\hline POL_4 & $\begin{array}{l}\text { I think it is right } \\
\text { that the Flemish } \\
\text { government spends } \\
\text { a lot of money } \\
\text { on non-native } \\
\text { speakers. }\end{array}$ & 3.02 & 0.91 & 3 & 2 & 36 & 55 & 24 & 9 \\
\hline POL_5 & $\begin{array}{l}\text { I think it is a pity } \\
\text { that non-native } \\
\text { speakers are obliged } \\
\text { to learn Dutch. }\end{array}$ & 1.54 & 0.69 & 1 & 68 & 52 & 2 & 4 & 0 \\
\hline SLA_1 & $\begin{array}{l}\text { Learning Dutch is } \\
\text { quite hard for non- } \\
\text { native speakers. }\end{array}$ & 4.02 & 0.89 & 4 & 1 & 9 & 15 & 62 & 39 \\
\hline SLA_2 & $\begin{array}{l}\text { It is normal for } \\
\text { non-native speakers } \\
\text { of Dutch to keep a } \\
\text { foreign accent. }\end{array}$ & 4.24 & 0.71 & 4 & 0 & 3 & 11 & 65 & 47 \\
\hline SLA_3 & $\begin{array}{l}\text { I expect non-native } \\
\text { speakers of Dutch } \\
\text { who intend to stay } \\
\text { in Flanders to lose } \\
\text { their foreign accent } \\
\text { after one year. }\end{array}$ & 1.47 & 0.68 & 1 & 78 & 39 & 7 & 2 & 0 \\
\hline SLA_4 & $\begin{array}{l}\text { I expect non-native } \\
\text { speakers who } \\
\text { intend to stay in } \\
\text { Flanders to learn } \\
\text { to speak Dutch } \\
\text { flawlessly. }\end{array}$ & 2.77 & 1.10 & 2 & 13 & 49 & 23 & 36 & 5 \\
\hline
\end{tabular}




\begin{tabular}{|c|c|c|c|c|c|c|c|c|c|}
\hline EFFORT_1 & $\begin{array}{l}\text { I find it tiring to } \\
\text { listen to non-native } \\
\text { speakers of Dutch. }\end{array}$ & 2.14 & 0.91 & 4 & 30 & 61 & 23 & 11 & 1 \\
\hline EFFORT_2 & $\begin{array}{l}\text { I continue to } \\
\text { listen to non- } \\
\text { native speakers } \\
\text { of Dutch, even } \\
\text { though it requires } \\
\text { a lot of effort to } \\
\text { understand them. }\end{array}$ & 4.21 & 0.74 & 2 & 1 & 3 & 9 & 68 & 45 \\
\hline EFFORT_3 & $\begin{array}{l}\text { I find it annoying } \\
\text { to make an effort } \\
\text { to understand non- } \\
\text { native speakers of } \\
\text { Dutch. }\end{array}$ & 2.05 & 0.85 & 4 & 32 & 66 & 18 & 10 & 0 \\
\hline EFFORT_4 & $\begin{array}{l}\text { Having a } \\
\text { conversation with } \\
\text { non-native speakers } \\
\text { requires a lot of } \\
\text { focus. }\end{array}$ & 3.55 & 0.79 & 2 & 1 & 14 & 32 & 73 & 6 \\
\hline STATUS_1 & $\begin{array}{l}\text { Dutch with a } \\
\text { foreign accent } \\
\text { is suitable for a } \\
\text { teacher. }\end{array}$ & 2.59 & 0.97 & 2 & 14 & 52 & 34 & 24 & 2 \\
\hline STATUS_2 & $\begin{array}{l}\text { It is okay for a } \\
\text { newsreader to } \\
\text { speak Dutch with a } \\
\text { foreign accent. }\end{array}$ & 2.48 & 1.06 & 2 & 23 & 49 & 28 & 23 & 3 \\
\hline STATUS_3 & $\begin{array}{l}\text { It bothers me when } \\
\text { a shop assistant } \\
\text { speaks Dutch with } \\
\text { a foreign accent. }\end{array}$ & 1.70 & 0.68 & 2 & 51 & 65 & 7 & 3 & 0 \\
\hline STATUS_4 & $\begin{array}{l}\text { I take a non-native } \\
\text { speaker of Dutch } \\
\text { less seriously. }\end{array}$ & 1.83 & 0.90 & 5 & 52 & 54 & 9 & 11 & 0 \\
\hline
\end{tabular}




\begin{tabular}{|c|c|c|c|c|c|c|c|c|c|}
\hline SOL_1 & $\begin{array}{l}\text { I could be friends } \\
\text { with a non-native } \\
\text { speaker who } \\
\text { doesn't speak } \\
\text { Dutch well. }\end{array}$ & 4.36 & 0.78 & 4 & 0 & 4 & 12 & 45 & 65 \\
\hline SOL_2 & $\begin{array}{l}\text { I trust non-native } \\
\text { speakers of Dutch. }\end{array}$ & 3.90 & 0.88 & 3 & 0 & 6 & 37 & 46 & 37 \\
\hline SOL_3 & $\begin{array}{l}\text { Most non-native } \\
\text { speakers of Dutch } \\
\text { go to great lengths } \\
\text { to integrate into } \\
\text { society. }\end{array}$ & 3.12 & 0.96 & 3 & 5 & 32 & 36 & 49 & 4 \\
\hline SOL_4 & $\begin{array}{l}\text { I feel safe with non- } \\
\text { native speakers. }\end{array}$ & 3.45 & 0.91 & 3 & 3 & 13 & 48 & 48 & 14 \\
\hline SOL_5 & $\begin{array}{l}\text { I enjoy interacting } \\
\text { with non-native } \\
\text { speakers in } \\
\text { Flanders. }\end{array}$ & 3.54 & 0.92 & 2 & 1 & 12 & 53 & 38 & 22 \\
\hline $\mathrm{EST}_{-} 1$ & $\begin{array}{l}\text { I think Dutch with } \\
\text { a foreign accent is } \\
\text { not attractive. }\end{array}$ & 2.22 & 0.92 & 3 & 30 & 50 & 34 & 12 & 0 \\
\hline EST_2 & $\begin{array}{l}\text { Dutch with a } \\
\text { foreign accent } \\
\text { sounds nice. }\end{array}$ & 3.06 & 0.73 & 3 & 4 & 17 & 73 & 31 & 1 \\
\hline INTELL_1 & $\begin{array}{l}\text { Non-native } \\
\text { speakers of Dutch } \\
\text { are often difficult } \\
\text { to understand. }\end{array}$ & 3.10 & 0.84 & 3 & 0 & 37 & 42 & 45 & 2 \\
\hline INTELL_2 & $\begin{array}{l}\text { Conversations with } \\
\text { non-native speakers } \\
\text { of Dutch often run } \\
\text { smoothly. }\end{array}$ & 2.98 & 0.84 & 3 & 1 & 41 & 46 & 36 & 2 \\
\hline INTELL_3 & $\begin{array}{l}\text { A conversation } \\
\text { with a non-native } \\
\text { speaker of Dutch } \\
\text { often leads to } \\
\text { misunderstandings. }\end{array}$ & 2.80 & 0.86 & 3 & 4 & 48 & 44 & 29 & 1 \\
\hline
\end{tabular}




\begin{tabular}{|c|c|c|c|c|c|c|c|c|c|}
\hline INTELL_4 & $\begin{array}{l}\text { I have to make } \\
\text { a huge effort to } \\
\text { understand non- } \\
\text { native speakers of } \\
\text { Dutch. }\end{array}$ & 2.82 & 0.83 & 2 & 2 & 51 & 41 & 32 & 0 \\
\hline VAR_1 & $\begin{array}{l}\text { Mistakes in Dutch } \\
\text { bother me. }\end{array}$ & 2.71 & 1.22 & 4 & 22 & 42 & 22 & 31 & 9 \\
\hline VAR_2 & $\begin{array}{l}\text { It is important that } \\
\text { everyone should } \\
\text { be able to speak } \\
\text { Standard Dutch. }\end{array}$ & 3.55 & 1.02 & 3 & 5 & 18 & 22 & 65 & 16 \\
\hline VAR_3 & $\begin{array}{l}\text { Dialect and } \\
\text { substandard } \\
\text { language may also } \\
\text { be used in public } \\
\text { broadcasting (radio } \\
\text { and television). }\end{array}$ & 2.99 & 1.14 & 3 & 12 & 39 & 20 & 48 & 7 \\
\hline
\end{tabular}

Below we present the associations which we found between the background variables age, educational level, extent of contact with L2 speakers and political preference, on the one hand, and the 34 statements probing social attitudes, on the other hand. There was a significant effect of age on 4 statements, of educational level on 5 statements, of extent of contact with L2 speakers on 3 statements and of political preference on 18 statements. At the same time, this means we observed no significant effect of age on 30 statements, of educational level on 29 statements, of extent of contact on 31 statements and of political preference on 16 statements.

We observed a significant effect of the age of our respondents on their answers to the statements LEARN_1, LEARN_2, EST_1 and VAR_3 (cf. Table 3). Even though all our respondents generally seemed to find it important for newcomers to learn Dutch (cf. Table 2), we did observe age differences: the older the respondents, the more strongly they believe newcomers have to learn Dutch (LEARN_1) and the more they feel annoyed when migrants have not succeeded in learning Dutch, despite having lived in Flanders for many years (LEARN_2). Older respondents are also significantly less tolerant towards the use of non-standard Dutch on radio and television (VAR_3). At the same time, though, our younger respondents seem to find Dutch with a foreign accent less attractive than the older ones (EST_1). 
Table 3. Statements with a significant effect of age (the intercept provides an estimate of the response variable at age 0;0). Between brackets are the $95 \%$ confidence intervals

\begin{tabular}{lrrrr}
\hline Beta & LEARN_1 & LEARN_2 & \multicolumn{1}{c}{ EST_1 } & VAR_3 \\
\hline \multirow{3}{*}{ Intercept } & 2.3770 & 1.8723 & 2.5224 & 5.2956 \\
& $(1.4004 ;$ & $(0.3812 ;$ & $(0.9542 ;$ & $(3.5002 ;$ \\
& $3.3535)$ & $3.3633)$ & $4.0906)$ & $7.0910)$ \\
\multirow{2}{*}{ AGE } & -0.0180 & -0.0178 & 0.0225 & -0.0525 \\
& $(-0.0294 ;$ & $(-0.0353 ;$ & $(0.0042 ;$ & $(-0.0734 ;$ \\
& $-0.0066)$ & $-0.0004)$ & $0.0409)$ & $-0.0315)$ \\
\hline
\end{tabular}

Besides age differences, we also observed a significant effect of the educational level of our respondents on their answers to the statements LEARN_3, POL_3, STATUS_4, SOL_3 and INTELL_2 (cf. Table 2). Note that secondary education: vocational schooling is the reference level of this categorical variable, so its estimated value (for each of the six statements) is represented by the intercept.

Table 4. Statements with a significant effect of educational level (compared to "secondary education: vocational schooling" as a reference point). Between brackets are the $95 \%$ confidence intervals

\begin{tabular}{lrrrrrr}
\hline Beta & LEARN_3 & POL_3 & STATUS_4 & SOL_1 & SOL_4 & VAR_3 \\
\hline \multirow{3}{*}{ Intercept } & 2.7395 & 2.8540 & 2.9568 & 3.1053 & 2.5064 & 5.2956 \\
& $(1.1884 ;$ & $(1.3672 ;$ & $(1.4451 ;$ & $(1.7992 ;$ & $(1.0031 ;$ & $(3.5002 ;$ \\
& $4.2906)$ & $4.3408)$ & $4.4685)$ & $4.4114)$ & $4.0097)$ & $7.0910)$ \\
\hline $\begin{array}{l}\text { Secondary } \\
\text { education: }\end{array}$ & 0.6770 & 1.1434 & 0.8188 & 0.3669 & 0.4887 & -0.9916 \\
technical & $(-0.4380 ;$ & $(0.0745 ;$ & $(-0.2680 ;$ & $(-0.5720 ;$ & $(-0.5921 ;$ & $(-2.2823 ;$ \\
schooling & $1.7921)$ & $2.2122)$ & $1.9055)$ & $1.3058)$ & $1.5694)$ & $0.2991)$ \\
\hline $\begin{array}{l}\text { Secondary } \\
\text { education: }\end{array}$ & 1.2748 & 1.7909 & 1.5054 & 0.7553 & 0.7981 & -1.0500 \\
general & $(0.1425 ;$ & $(0.7055 ;$ & $(0.4018 ;$ & $(-0.1982 ;$ & $(-0.2994 ;$ & $(-2.3607 ;$ \\
schooling & $2.4072)$ & $2.8763)$ & $2.6090)$ & $1.7087)$ & $1.8956)$ & $0.2607)$ \\
\hline $\begin{array}{l}\text { Bachelor's } \\
\text { degree }\end{array}$ & 1.2596 & 1.2745 & 0.9987 & 0.7022 & 0.6797 & -1.2142 \\
\hline $\begin{array}{l}\text { Master's } \\
\text { degree }\end{array}$ & $(0.1951 ;$ & $(0.2541 ;$ & $(-0.0388 ;$ & $(-0.1942 ;$ & $(-0.3521 ;$ & $(-2.4464 ;$ \\
& $2.3241)$ & $2.2949)$ & $2.0362)$ & $1.5985)$ & $1.7114)$ & $0.0180)$ \\
\hline & 1.6186 & 1.7326 & 1.0635 & 0.9562 & 1.1510 & -1.3785 \\
& $(0.4949 ;$ & $(0.6555 ;$ & $(-0.0317 ;$ & $(0.0100 ;$ & $(0.0619 ;$ & $(-2.6793 ;$ \\
& $2.7424)$ & $2.8098)$ & $2.1587)$ & $1.9025)$ & $2.2402)$ & $-0.0777)$ \\
\hline
\end{tabular}


The participants with a lower educational level more strongly believed that there are too many non-native speakers of Dutch in Flanders (LEARN_3, see Figure 1) and were less positive about the government spending large sums of money on Dutch language classes for non-native speakers (POL_3). We observe a similar impact of educational level on the extent to which respondents take non-native speakers of Dutch seriously (STATUS_4), the extent to which they believe that most non-native speakers of Dutch go to great lengths to integrate into society (SOL_3) and the extent to which they have the impression conversations with non-native speakers of Dutch run smoothly (INTELL_2).

Figure 1. Responses to LEARN_3 ("Many non-native speakers make an effort to learn Dutch") in relation to educational background

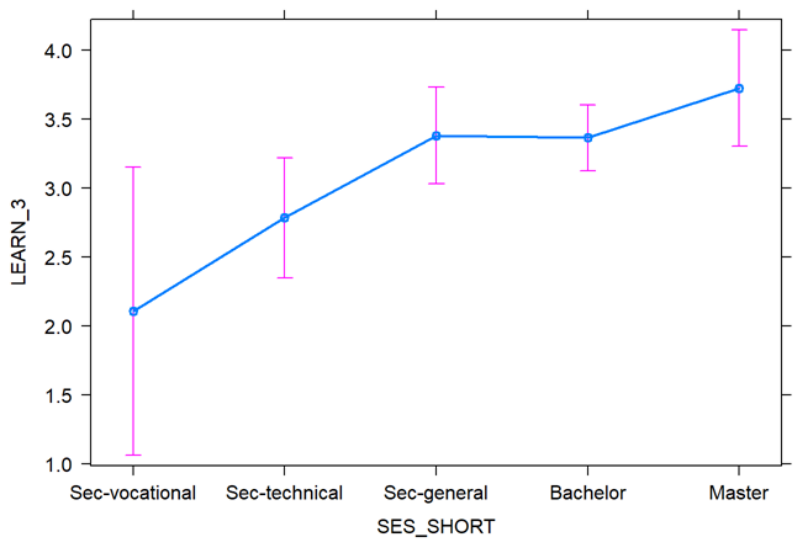

In all statements, we observe less positive attitudes in respondents with a qualification in vocational and technical secondary education than in respondents with a qualification in general secondary education or with a Bachelor's or Master's degree. This does not mean that respondents with a lower educational qualification always held negative attitudes, but their attitudes were less positive than those of respondents with a higher educational qualification. For instance, most of the respondents disagreed with the statement that they take non-native speakers less seriously, but respondents with a higher educational qualification disagreed more strongly (cf. Table 2).

The background variable extent of contact with L2 speakers showed an effect with the statements SOL_1, SOL_5 and INTELL_2 (cf. Table 5). In general, most respondents seemed to (completely) agree with $\mathrm{SOL}_{-} 5$ and especially SOL_1: they were quite positive about contacts with L2 speakers (cf. Table 2). In addition, we observed some differences depending on the extent of contact with L2 speakers: the 
more contact respondents have with non-native speakers of Dutch, the more they feel they could be friends with them (SOL_1) and the more they enjoy interacting with them (SOL_5). They also more strongly believe conversations with non-natives often run smoothly (INTELL_2).

Table 5. Statements with a significant effect of extent of contact (compared to respondents who are "rarely or never" in contact with non-native speakers as a reference point). Between brackets are the $95 \%$ confidence intervals

\begin{tabular}{lrrrrr}
\hline Beta & EFFORT_1 & SOL_1 & SOL_2 & SOL_5 & INTELL_2 \\
\hline \multirow{3}{*}{ Intercept } & 2.1419 & 3.1053 & 2.3660 & 2.9775 & 2.3011 \\
& $(0.5677 ;$ & $(1.7992 ;$ & $(0.9272 ;$ & $(1.5249 ;$ & $(0.8889 ;$ \\
& $3.7162)$ & $4.4114)$ & $3.8047)$ & $4.4301)$ & $3.7133)$ \\
\hline \multirow{2}{*}{ Monthly } & 0.4978 & 0.3771 & 0.4445 & 0.4781 & 0.7072 \\
\multirow{2}{*}{ contact } & $(-0.1389 ;$ & $(-0.1511 ;$ & $(-0.1373 ;$ & $(-0.1094 ;$ & $(0.1361 ;$ \\
& $1.1344)$ & $0.9053)$ & $1.0264)$ & $1.0655)$ & $1.2783)$ \\
\multirow{2}{*}{ Weekly } & 0.3913 & 0.4228 & 0.3348 & 0.3089 & 0.3390 \\
contact & $(-0.2248 ;$ & $(-0.0883 ;$ & $(-0.2283 ;$ & $(-0.2596 ;$ & $(-0.2137 ;$ \\
& $1.0074)$ & $0.9340)$ & $0.8978)$ & $0.8773)$ & $0.8917)$ \\
\multirow{2}{*}{ Daily } & 0.7716 & 0.9110 & 0.6864 & 1.0175 & 0.7241 \\
contact & $(0.1132 ;$ & $(0.3647 ;$ & $(-0.2283 ;$ & $(0.4099 ;$ & $(0.1335 ;$ \\
& $1.4300)$ & $1.4573)$ & $0.8978)$ & $1.6250)$ & $1.3147)$ \\
\hline
\end{tabular}

The background variable which showed most significant effects is political preference. There is a significant effect of political preference on the answers of the following 18 statements: LEARN_1, LEARN_2, LEARN_3, POL_1, POL_2, POL_3, POL_4, POL_5, STATUS_2, STATUS_3, STATUS_4, SOL_2, SOL_3, SOL_4, SOL_5, EST_1, INTELL_1 and SLA_4 (cf. Table 6). 
Table 6. Statements with a significant effect of political preference (compared to leftwing respondents as a reference point). Between brackets are the $95 \%$ confidence intervals

\begin{tabular}{|c|c|c|c|c|c|c|}
\hline Beta & LEARN_1 & LEARN_2 & LEARN_3 & POL_1 & POL_2 & $\mathrm{POL}_{-} 3$ \\
\hline Intercept & $\begin{array}{r}2.3770 \\
(1.4004 ; \\
3.3535)\end{array}$ & $\begin{array}{r}1.8723 \\
(0.3812 \\
3.3633)\end{array}$ & $\begin{array}{r}2.7395 \\
(1.1884 ; \\
4.2906) \\
\end{array}$ & $\begin{array}{r}3.8861 \\
(2.2780 \\
5.4942) \\
\end{array}$ & $\begin{array}{r}3.2509 \\
(1.8627 ; \\
4.6391) \\
\end{array}$ & $\begin{array}{r}2.8540 \\
(1.3672 ; \\
4.3408)\end{array}$ \\
\hline Central & $\begin{array}{r}-0.2303 \\
(-0.5203 ; \\
0.0598)\end{array}$ & $\begin{array}{r}-0.2732 \\
(-0.7161 ; \\
0.1696)\end{array}$ & $\begin{array}{r}-0.5648 \\
-1.0255 ; \\
-0.1041)\end{array}$ & $\begin{array}{c}-0.5441 \\
(-1.0217 \\
-0.0665)\end{array}$ & $\begin{array}{r}-0.7473 \\
(-1.1596 \\
-0.3350)\end{array}$ & $\begin{array}{r}-0.1732 \\
(-0.6148 ; \\
0.2684)\end{array}$ \\
\hline $\begin{array}{l}\text { Right- } \\
\text { wing }\end{array}$ & $\begin{array}{r}-0.5140 \\
(-0.8089 ; \\
-0.2191)\end{array}$ & $\begin{array}{r}-0.9367 \\
(-1.3870 \\
-0.4865)\end{array}$ & $\begin{array}{r}-0.9611 \\
(-1.4296 \\
-0.4927)\end{array}$ & $\begin{array}{r}-1.2971 \\
(-1.7827 \\
-0.8114)\end{array}$ & $\begin{array}{c}-0.9043 \\
(-1.3236 \\
-0.4851)\end{array}$ & $\begin{array}{r}-0.5326 \\
(-0.9816 ; \\
-0.0836)\end{array}$ \\
\hline Beta & POL_4 & POL_5 & EST_1 & STATUS_2 & STATUS_3 & STATUS_4 \\
\hline Intercept & $\begin{array}{r}4.2000 \\
(2.8221 ; \\
5.5779)\end{array}$ & $\begin{array}{r}2.1267 \\
(0.9660 \\
3.2873)\end{array}$ & $\begin{array}{r}2.5224 \\
(0.9542 \\
4.0906)\end{array}$ & $\begin{array}{r}3.2066 \\
(1.3581 ; \\
5.0550)\end{array}$ & $\begin{array}{r}3.8876 \\
(2.7331 ; \\
5.0421)\end{array}$ & $\begin{array}{r}2.9568 \\
(1.4451 ; \\
4.4685)\end{array}$ \\
\hline Central & $\begin{array}{r}-0.4249 \\
(-0.8342 ; \\
-0.0157)\end{array}$ & $\begin{array}{r}-0.3812 \\
(-0.7259 \\
-0.0365)\end{array}$ & $\begin{array}{r}-0.4614 \\
(-0.9272 ; \\
0.0044)\end{array}$ & $\begin{array}{r}-0.0191 \\
(-0.5681 \\
0.5300)\end{array}$ & $\begin{array}{c}-0.3758 \\
(-0.7187 \\
-0.0329)\end{array}$ & $\begin{array}{r}-0.3485 \\
(-0.7975 \\
0.1005) \\
\end{array}$ \\
\hline $\begin{array}{l}\text { Right- } \\
\text { wing }\end{array}$ & $\begin{array}{r}-1.1305 \\
(-1.5466 ; \\
-0.7144)\end{array}$ & $\begin{array}{r}-0.6084 \\
(-0.9589 \\
-0.2579)\end{array}$ & $\begin{array}{c}-0.6033 \\
(-1.0769 ; \\
-0.1297)\end{array}$ & $\begin{array}{r}-0.6484 \\
(-1.2067 ; \\
-0.0902)\end{array}$ & $\begin{array}{r}-0.5551 \\
(-0.9037 ; \\
-0.2065)\end{array}$ & $\begin{array}{r}-0.6383 \\
(-1.0948 ; \\
-0.1818)\end{array}$ \\
\hline Beta & $\mathrm{SOL}_{-} 2$ & $\mathrm{SOL}_{-} 3$ & $\mathrm{SOL}_{-} 4$ & $\mathrm{SOL} \_5$ & INTELL_1 & SLA_4 \\
\hline Intercept & $\begin{array}{r}2.3660 \\
(0.9272 \\
3.8047) \\
\end{array}$ & $\begin{array}{r}2.8390 \\
(1.2885 ; \\
4.3895) \\
\end{array}$ & $\begin{array}{r}2.5064 \\
(1.0031 ; \\
4.0097) \\
\end{array}$ & $\begin{array}{r}2.9775 \\
(1.5249 \\
4.4301) \\
\end{array}$ & $\begin{array}{r}2.2757 \\
(0.8271 \\
3.7244) \\
\end{array}$ & $\begin{array}{r}4.5772 \\
(2.6524 ; \\
6.5020) \\
\end{array}$ \\
\hline Central & $\begin{array}{r}0.1352 \\
(-0.2921 ; \\
0.5626)\end{array}$ & $\begin{array}{r}-0.2480 \\
(-0.7085 ; \\
0.2125)\end{array}$ & $\begin{array}{r}-0.2003 \\
(-0.6468 \\
0.2462)\end{array}$ & $\begin{array}{r}-0.1438 \\
(-0.5753 ; \\
0.2876)\end{array}$ & $\begin{array}{r}-0.2164 \\
(-0.6466 \\
0.2139)\end{array}$ & $\begin{array}{r}-0.3630 \\
(-0.9347 ; \\
0.2087)\end{array}$ \\
\hline $\begin{array}{l}\text { Right- } \\
\text { wing }\end{array}$ & $\begin{array}{r}-0.2965 \\
(-0.7309 \\
0.1380)\end{array}$ & $\begin{array}{c}-0.8034 \\
(-1.2717 \\
-0.3352)\end{array}$ & $\begin{array}{c}-0.7378 \\
(-1.1918 \\
-0.2838)\end{array}$ & $\begin{array}{r}-0.6196 \\
(-1.0583 ; \\
-0.1810)\end{array}$ & $\begin{array}{c}-0.6596 \\
(-1.0971 ; \\
-0.2221)\end{array}$ & $\begin{array}{r}-0.8279 \\
(-1.4092 ; \\
-0.2466)\end{array}$ \\
\hline
\end{tabular}

Even though most respondents seem to agree with the statements LEARN_1 and LEARN_2 (cf. Table 2), the right-wing respondents more strongly believe that 
newcomers who want to continue living in Flanders have to learn Dutch (LEARN_1) and they feel more annoyed when migrants have not learned the language after having lived in Flanders for many years (LEARN_2). Right-wing respondents are also less convinced that many non-native speakers in Flanders make an effort to learn Dutch (LEARN_3). Moreover, they have higher expectations regarding the level of Dutch learners have to attain than left-wing respondents: they more strongly believe that newcomers should learn to speak Dutch flawlessly (SLA_4), as shown in Figure 2.

Figure 2. Responses to SLA_4 ("I expect non-native speakers who intend to stay in Flanders to learn to speak Dutch flawlessly”) in relation to political preference

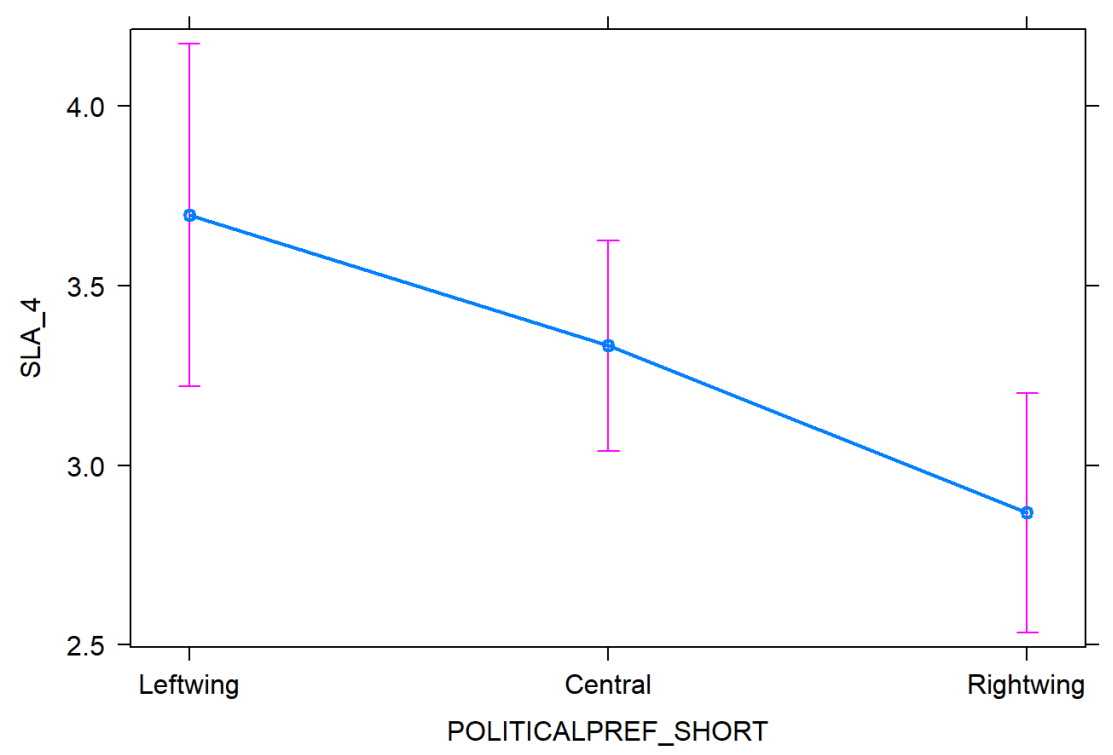

As is clear from Figure 2 about SLA_4, the answers of respondents who situate themselves mid-spectrum politically, lie somewhere in between left- and right-wing. This is also the case for the other statements mentioned in Table 6 .

Especially the answers to the statements we categorised under "Political preference" (and more specifically statements POL_1 and POL_4) seemed to cause division between the respondents (cf. Table 2). The right-wing respondents agree more often with the statement that there are too many non-native speakers of Dutch in Flanders (POL_1). They also more strongly believe that the government spends too much money on Dutch language classes for non-native speakers (POL_2, POL_3) and they approve less often of the fact that the Flemish government spends a lot of money on non-native speakers in general (POL_4). Compared to left-wing respondents, they 
agreed more strongly or disagreed less strongly with the statement "I think it is a pity that non-native speakers should be obliged to learn Dutch" (POL_5).

Even though none of our respondents were really open to the idea of a newsreader speaking with a non-native accent of Dutch (STATUS_2: $\mathrm{M}=2.48$; $\mathrm{SD}=1.06$ ), rightwing respondents were still less fond of the idea. In general, all our respondents were less bothered by the idea that a shop assistant would have a foreign accent in Dutch (STATUS_3), but we again observe differences between right-wing and left-wing respondents. The right-wing respondents also take non-native speakers of Dutch less seriously (STATUS_4).

In the same vein, right-wing respondents are less trusting of non-native speakers (SOL_2) and feel less safe with them (SOL_4). They also enjoy having contact with them less than central and left-wing respondents (SOL_5). Moreover, they are less convinced than central and left-wing respondents that most non-native speakers of Dutch go to great lengths to integrate into society (SOL_3). Finally, they more strongly believe that Dutch with a foreign accent is unattractive (EST_1) and that non-native speakers of Dutch are often difficult to understand (INTELL_1).

\subsection{Listener's evaluations of non-native speakers/speech}

To answer the question if listeners' evaluations of non-native speakers and nonnative speech can predict the perceived foreign accentedness, comprehensibility and intelligibility of non-native speech (RQ2), we first needed to check (1) if significant differences could be observed between the two speakers in these respects and (2) if the 17 statements of the speaker/speech evaluation experiment can be grouped into dimensions.

\subsubsection{Comparison of speakers and contexts}

The 102 respondents in the second part of our study did not rate the two speakers significantly different in terms of comprehensibility. For intelligibility (i.e., the accuracy with which target words were transcribed by participants), however, there was a significant interaction between the two speakers and the two contexts (cf. Table 7). This is visualized in Figure 3. 
Table 7. Effect of speaker and context on intelligibility (with speaker A and "CONTEXT:Real" as reference points)

\begin{tabular}{lccc}
\hline & Estimate & $2.5 \%$ & $97.5 \%$ \\
\hline (Intercept) & 0.9020 & 0.8771 & 0.9269 \\
\hline SPEAKER:B & 0.0283 & -0.0037 & 0.0602 \\
\hline CONTEXT:Nonsense & -0.0553 & -0.0873 & -0.0233 \\
\hline SPEAKER:B x & -0.2096 & -0.2548 & -0.1644 \\
CONTEXT:Nonsense & & & \\
\hline
\end{tabular}

Figure 3. Intelligibility speaker A vs. speaker B (percentage of correctly transcribed items) and nonsensical ("nonsense") vs. semantically meaningful ("real") sentences

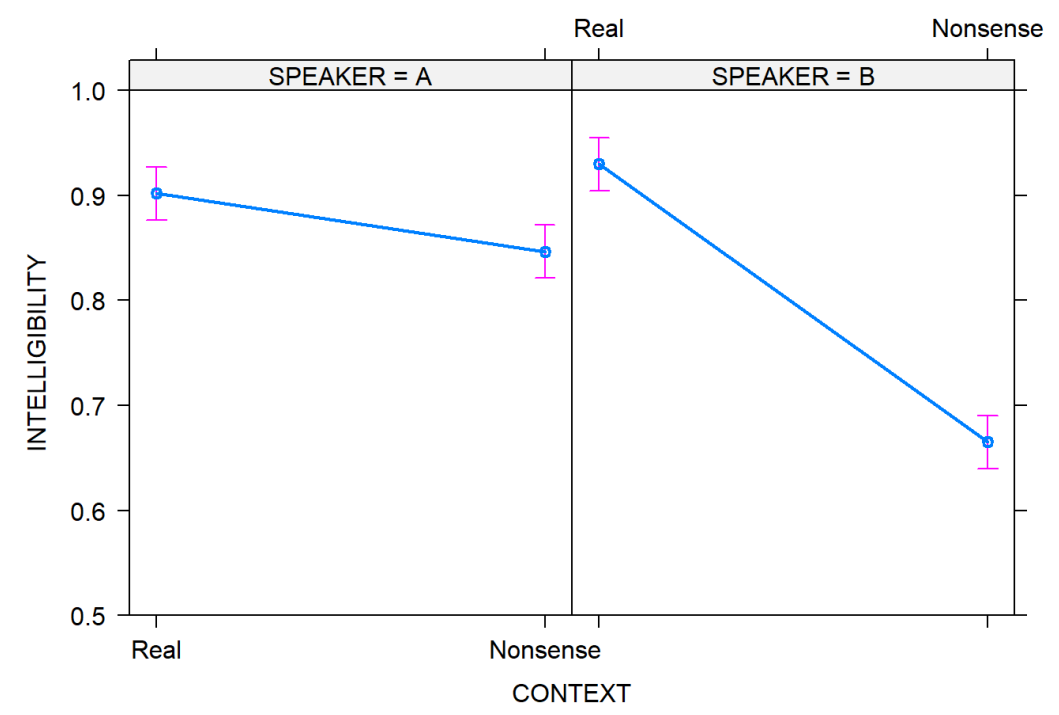

Figure 3 shows that for both speakers the intelligibility score for the semantically meaningful sentences is significantly higher than for the nonsensical sentences; in the nonsensical sentences, speaker B is significantly less intelligible than speaker A. This means that we have to study the impact of the evaluations of non-native speakers and speech on the intelligibility of these two speakers and two contexts separately.

We also observed significant differences between the two speakers in terms of strength of foreign accent: speaker B is assigned a less strong accent than speaker A, which is surprising as speaker B received a lower intelligibility score for the nonsense sentences (cf. Table 8). 
Table 8. Effect of speaker on (strength of) foreign accent (with "Speaker A" as reference point)

\begin{tabular}{lrrr|}
\hline & Estimate & $2.5 \%$ & $97.5 \%$ \\
\hline (Intercept) & 3.9753 & 3.8516 & 4.0989 \\
\hline SPEAKER:B & -0.2545 & -0.4006 & -0.1084 \\
\hline
\end{tabular}

\subsubsection{PCA of the speaker/speech evaluation experiment}

Principal component analysis with Varimax rotation revealed that the responses to the 17 statements of the speaker/speech evaluation task correlated in five dimensions, which could be identified as "effort required from listener", "solidarity", "accent appreciation", "status" and "level of integration". Table 9 gives an overview of the dimensions and statements within these dimensions. As a result, the analyses in Sections 4.2.3, 4.2.4 and 4.2.5 are based on these five dimensions. 
Table 9. PCA speaker/speech evaluation experiment

Variable

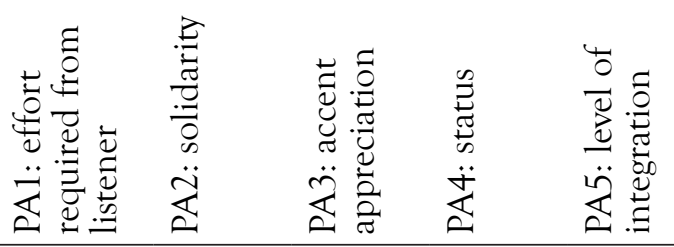

Understanding this speaker requires 0.861

a lot of focus.

I find it hard/difficult to listen to $\quad 0.811$

this speaker.

I find it easy to understand this $\quad 0.771$

speaker.

I find the language of this speaker $\quad 0.763$

irritating.

I find the language of this speaker $\quad 0.643$

beautiful.

I think this speaker can be trusted. $\quad 0.865$

$\begin{array}{ll}\text { I think this speaker is a fun person. } & 0.739\end{array}$

I think this speaker has a lot of $\quad 0.617$

friends.

I think this speaker is unemployed. $\quad 0.590$

I find this speaker's foreign accent funny.

I find the foreign accent of this $\quad 0.776$

speaker cute.

I like the foreign accent of this 0.753

speaker.

I think this speaker has a degree in $\quad 0.730$

higher education.

$\begin{array}{ll}\text { I think this speaker holds a high } & 0.870\end{array}$ position.

I think this speaker is well

integrated in Flanders.

I think this person has adapted to

the social norms and customs in

Flanders.

I think this speaker knows many

0.579

Dutch speakers in Flanders. 


\subsubsection{Comprehensibility ws. speaker/speech evaluation}

Although the 17 attitude questions were asked about speakers A and B separately, there were no significant differences between the two speakers in terms of the five attitude variables from the PCA. This allowed us to limit ourselves to studying the main effects of the five attitude variables on comprehensibility and foreign accent. We observed a significant effect of the attitude variables "effort required from the listener" (PA1) and "status" (PA4) on comprehensibility, as shown in Table 10.

Table 10. Effects of attitude variables PA1 ("Effort required from listener") and PA4 ("Status") on comprehensibility

\begin{tabular}{lccc}
\hline & Estimate & $2.5 \%$ & $97.5 \%$ \\
\hline (Intercept) & 3.8088 & 3.6856 & 3.9320 \\
\hline $\begin{array}{l}\text { PA1: effort required from the } \\
\text { listener }\end{array}$ & 0.3461 & 0.2284 & 0.4644 \\
\hline PA4: status & 0.1913 & 0.0646 & 0.3180 \\
\hline
\end{tabular}

The less effort it took respondents to understand the speakers (PA1) and the higher the speakers were rated on the status dimension (PA4), the higher they were also rated for comprehensibility.

\subsubsection{Perceived foreign accent vs. speaker/speech evaluation experiment}

In the evaluation of foreign accent, our 102 respondents gave a significantly different rating to the two speakers (cf. Section 3.2.2.2). The foreign accent of speaker A is perceived to be stronger than that of speaker B, as shown in Table 11 .

Table 11. Effect of attitude variables PA1 ("Effort required from the listener"), PA2 ("Solidarity") and PA4 (“Status") on perceived foreign accent

\begin{tabular}{lccc}
\hline & Estimate & $2.5 \%$ & $97.5 \%$ \\
\hline (Intercept) & 3.9753 & 3.8516 & 4.0989 \\
\hline SPEAKER:B & -0.2545 & -0.4006 & -0.1084 \\
\hline $\begin{array}{l}\text { PA1: effort required from the } \\
\text { listener }\end{array}$ & -0.2874 & -0.3883 & -0.1864 \\
\hline PA2: solidarity & 0.1220 & 0.0202 & 0.2238 \\
\hline PA4: status & -0.1443 & -0.2516 & -0.0370 \\
\hline
\end{tabular}


We observed a significant effect of the attitude variables "effort required from listener" (PA1), "solidarity" (PA2) and "status" (PA4) on the evaluation of foreign accent. These three effects were the same for both speakers (since none of the interaction effects of the attitude variables with speaker were statistically significant).

Foreign accent is perceived to be stronger when it requires more effort to understand the speakers (PA1) and the speakers were rated higher on the solidarity (PA2) and lower on the status dimension (PA4) when their foreign accent was perceived to be stronger.

\subsubsection{Intelligibility vs. speaker/speech evaluation experiment}

Concerning intelligibility, there was a significant difference between the two speakers. The difference resided in the effect of the attitude variable "level of integration" (PA5) on their intelligibility, as visualized in Figure 4. Figure 4 shows that, whereas the attitude variable appeared to adversely affect the intelligibility of speaker A, it proved to have a positive bearing on the intelligibility of speaker B. This means that listeners who believed speaker A to be better integrated in Flanders (higher score on the X-axis) had greater difficulty understanding that speaker than listeners who believed the speaker to be less well integrated. The opposite trend was observed for speaker B.

Figure 4. Effect of "level of integration" on intelligibility of speaker A and B

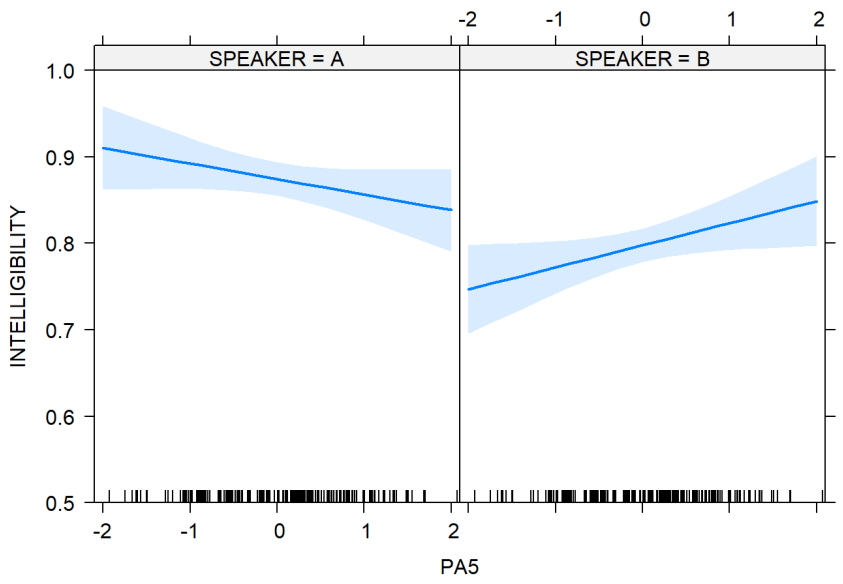

We also observed a significant difference between the two contexts (i.e. meaningful sentences vs. nonsensical sentences) in the effect of the attitude variable "effort required 
from the listener" on the intelligibility of both speakers (cf. Figure 5; see Table 12). In other words, listeners who believed that conversations with the non-native speakers would require a lot of effort from them were better able to understand the speakers in the real sentences, but the reverse was true in the nonsensical sentences.

Figure 5. Effect of effort required from the listener on intelligibility in semantically meaningful ("real") and nonsensical ("nonsense") sentences

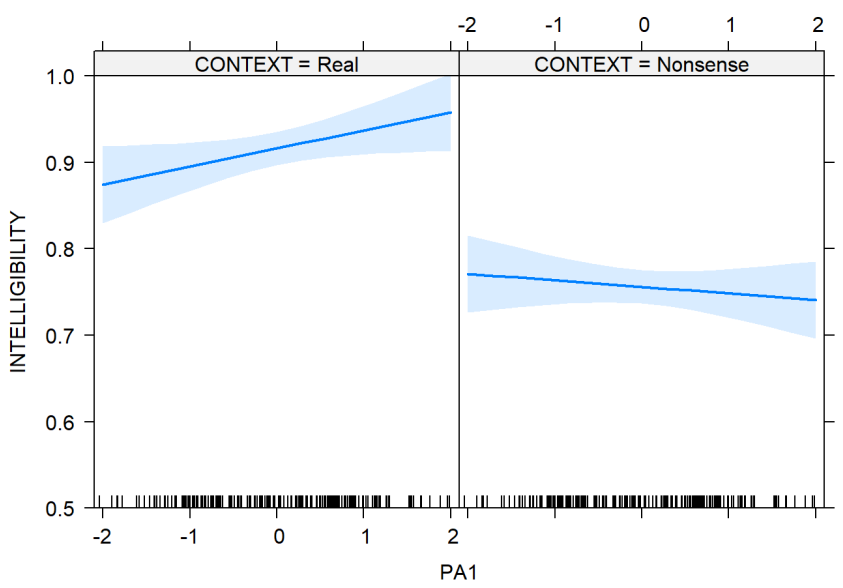

Table 12. Effect of attitude variables PA1 ("Effort required from the listener") and PA5 ("Level of integration") on intelligibility

\begin{tabular}{lccc}
\hline & Estimate & $2.5 \%$ & $97.5 \%$ \\
\hline (Intercept) & 0.9020 & 0.8771 & 0.9269 \\
\hline SPEAKER:B & 0.0283 & -0.0037 & 0.0602 \\
\hline CONTEXT:Nonsense & -0.0553 & -0.0873 & -0.0233 \\
\hline PA5: level of integration & -0.0179 & -0.0397 & 0.0039 \\
\hline $\begin{array}{l}\text { PA1: effort required from the } \\
\text { listener }\end{array}$ & 0.0210 & 0.0011 & 0.0409 \\
\hline $\begin{array}{l}\text { SPEAKER:B x } \\
\text { CONTEXT:Nonsense }\end{array}$ & -0.2096 & -0.2548 & -0.1644 \\
\hline $\begin{array}{l}\text { SPEAKER:B x PA5: level of } \\
\text { integration }\end{array}$ & 0.0435 & 0.0139 & 0.0731 \\
\hline \begin{tabular}{l} 
CONTEXT: Nonsense x PA1 \\
\hline
\end{tabular} & -0.0286 & -0.0533 & -0.0038 \\
\hline
\end{tabular}




\section{Discussion}

This study had two main research aims. The first aim was to investigate whether the listener characteristics "age", "level of education", "extent of contact with L2 speakers" and "political preference" predict listeners' attitudes towards non-native speakers and non-native speech in general. To this end, 126 Dutch-speaking Belgian respondents completed a 34-item questionnaire probing their views on themes such as the effort needed to communicate with non-native speakers, the status of non-native speakers, solidarity towards non-native speakers and the effort invested by non-native speakers in learning Dutch. Previous studies aimed at determining which factors predict respondents' social attitudes tend to focus on attitudes towards migrants and refugees (e.g. Chandler \& Tsai, 2001; Butkus, Maciulyte-Sniukiene \& Matuzeviciute, 2016; Murray \& Marx, 2013; see Section 2.2). We hypothesized that the same characteristics would help to explain people's social attitudes towards non-native speakers and their speech in general, i.e. without the respondents' knowledge whether these speakers are immigrants or refugees or neither. The results of the analysis of the questionnaire data in relation to respondents' background characteristics confirmed this hypothesis, in the sense that all four factors - "age", "level of education", "extent of contact with L2 speakers" and "political preference" - predicted the responses to a number of statements. As far as the age of the respondents is concerned, we found that the results are generally in line with Butkus et al.'s (2016) claim that more tolerant social attitudes are typically associated with youth: younger respondents were found to be generally less insistent on newcomers having to learn Dutch as soon as possible, less bothered by newcomers who have not learnt Dutch (well) yet and more tolerant towards variation in Dutch (e.g. towards native but substandard accents in the media (radio and television) than older respondents. The educational level of the respondents also proved to play a role, in that we observed more positive attitudes towards nonnative speakers and their speech in respondents with a higher level of education. For instance, these respondents generally did not agree that there are too many nonnative speakers of Dutch in Flanders, they thought it is right that Dutch language classes are government-funded and agreed that most non-native speakers of Dutch go to great lengths to integrate into society. These findings are in line with previous studies on social attitudes towards immigrants or refugees. Those studies hypothesize that the absence of economic competition with newcomers and the more diverse and cosmopolitan networks of people with a higher educational level foster tolerance (Butkus et al., 2016; Chandler \& Tsai, 2001). Previous findings are also confirmed for the variable "extent of contact with L2 speakers": respondents who reported to have more contact also felt more strongly that they could be friends with non-native speakers and believed conversations with non-native speakers to generally run smoothly (cf. the Contact Theory mentioned in Section 2.2, Butkus et al., 2016). Finally, we observed a 
significant correlation between political preference and the answers to 18 statements including statements related to the status of and solidarity with non-native speakers and the aesthetic value of accented speech. For instance, respondents who described their political ideology as right-wing have higher expectations of the level of Dutch that learners have to attain, are significantly less convinced that many non-native speakers in Flanders make an effort to learn Dutch, trust non-native speakers significantly less and feel significantly less safe with them. The answers of the respondents who characterize their political ideology as "centrist" typically lie somewhere in between left- and right-wing. These findings are in line with earlier studies on the correlation between political stance and social attitudes towards immigrants, which have shown that people with right-wing or conservative political ideologies tend to adopt a more negative stance towards newcomers (Chandler \& Tsai, 2001).

In conclusion, a number of statements led to responses which could be predicted by the four listener characteristics discussed. However, it is also important to mention that for many of the statements, no effect of these characteristics was observed. For instance, we found that the variable "age" predicted responses to 4 statements, meaning that it had no predictive power for responses to the remaining 30 statements. The same holds true for educational level (significant predictor for $5 / 34$ statements) and extent of contact with L2 speakers (significant predictor for 3/34 statements). In other words, the impact of "age", "level of education" and "contact with L2 speakers" is certainly present, but it does not predict the responses to the majority of statements viz. non-native speakers and non-native speech. The effect of political preference proved to be considerably stronger: respondents' self-confessed political ideology predicted their responses to 18 out of 34 statements. The strong predictive power of political preference is not surprising, as it has been observed that migration policy is one of the most important electoral motives in Belgium and voting behaviour is strongly influenced by attitudes towards immigrants and, by extension, towards non-native speakers (Deschouwer et al., 2010). We should, however, also add a cautionary note here. The participants were recruited from the researchers' social networks through social media (e.g. Facebook profiles of Master students involved in the recruitment procedure). This means that the sample may not be representative of the larger population. For instance, participants with a Bachelor's, Master's or PhD degree seem to be overrepresented. The sampling method may thus, to a certain extent, skew the results.

In the second part of the study, we establish the link between people's social attitudes towards non-native speakers and the intelligibility of non-native speech. Specifically, the second aim of the study was to investigate whether listeners' evaluations of non-native speakers and their speech predict their responses with regard 
to intelligibility, comprehensibility and (foreign) accentedness of these speakers. To answer this question, 122 respondents performed speaker and speech evaluation tasks with samples of L2 Dutch speech produced by two native speakers of Mandarin Chinese with a high proficiency in Dutch. The results of these speaker/speech evaluation experiments were analysed in relation to respondents' performance on a transcription task and their ratings of the speakers' comprehensibility and accentedness. A comparison between the two speakers showed that listeners rated the speakers significantly differently for foreign accentedness, but not for comprehensibility. As far as intelligibility is concerned, the results of the transcription task showed that the intelligibility scores for the semantically meaningful sentences were significantly higher than for the nonsensical sentences. This suggests, as corroborated by Kang et al. (2018) (see Section 2.1.), that listeners do use available semantic context when performing intelligibility tasks. The speaker who was rated as having a stronger (foreign) accent, actually turned out to be more intelligible on the items in the nonsensical sentences than the speaker with the milder accent. These results are in line with earlier research by, among others, Munro \& Derwing (1995a) and Derwing \& Munro (1997), which shows that intelligibility, comprehensibility and accentedness are indeed different and partly independent constructs.

The analysis further reveals that the responses to the statements of the speaker/ speech evaluation task correlated in five dimensions, which could be identified as "effort required from listener", "solidarity", "accent appreciation", "status" and "level of integration". We hypothesized that listeners' responses in the speaker/speech evaluation experiment would have an effect on the intelligibility, comprehensibility and accentedness of these same speakers. Since previous research shows mixed results, we predicted that this effect is a subtle one (see Section 3.1.). As far as comprehensibility and foreign accentedness are concerned, we did find a significant correlation between these variables and a number of attitudinal dimensions. For instance, respondents who rated the speakers high for comprehensibility also rated them higher on the status dimension. Similarly, respondents who considered the speakers to have a stronger foreign accent also reported it took more effort to understand them, and they rated them lower on the status dimension. Finally, we observed no significant correlations between any of the five attitude dimensions and intelligibility scores. We only found that the attitude variable "level of integration" impacted the two speakers differently. We also observed a significant difference between the meaningful and nonsensical sentences in the effect of the attitude variable "effort required from the listener" on the intelligibility of both speakers. These findings suggest that the link between listeners' attitudes and their scores on a transcription task measuring speakers' intelligibility is not straightforward, i.e., we can, for instance, not conclude that listeners holding, negative attitudes towards non-native speakers understand non-native speech less well 
than listeners with a more positive attitude. The results indicate that the relationship between listeners' attitudes and the intelligibility of non-native speakers is subject to both speaker and task effects. It is, for instance, possible that an effect of attitudes on the success of communication with non-native speakers can only be observed when direct and personal interaction with non-native speakers is part of the experimental design, as in Lindeman (2002; cf. Section 2.2). Whether communication is successful or not, clearly depends on much more than on the intelligibility of individual words. Segmental as well as prosodic aspects play a role (Caspers \& Horloza, 2012) and, above all, conversations do not take place in a situational vacuum, but are embedded in a social and cultural context (Rajadurai, 2007). In the present study, the L2 Dutch speech samples of the L1 Mandarin Chinese speakers were presented only aurally, without a face attached to them. This may have diminished the influence of social attitudes on the perception of the non-native speech.

\section{Conclusions and suggestions for further research}

As many Western societies become increasingly diverse due to mobility and migration, the number of people communicating with non-native speakers is rapidly growing and tolerance as a social attitude is becoming more and more imperative (Hooghe, Meeusen \& Quintelier, 2013). In this study, we set out to explore people's background characteristics affecting social attitudes towards non-native speakers, as well as the effect of these attitudes on the intelligibility, comprehensibility and accentedness of non-native speech. The results of a survey confirmed that the listeners' age, level of education, extent of contact with L2 speakers and, above all, their political preference predicted their social attitudes. Younger, highly educated people who had more contact with non-native speakers and situated themselves more towards the left of the political spectrum, had more lenient attitudes towards non-native speakers and their speech. The result of the experimental part of the study confirmed that there was a link between people's evaluations of non-native speakers and their speech and measures of comprehensibility and accentedness. Listeners who rated the speakers high on the status dimension also reported they found them more comprehensible. Conversely, listeners who rated the speakers low on the status dimension reported hearing a stronger foreign accent and experiencing greater difficulty understanding the speakers. While it is open to debate whether the listeners' attitudes affected their comprehensibility and accentedness judgments or vice versa, the results show that there is a correlation between attitudes on the one hand and comprehensibility and accentedness judgments on the other hand. We should obviously be careful when generalizing the results. In the current study, both non-native speakers of Dutch in Part 2 of the research are native speakers of Mandarin Chinese. It is well-known that 
attitudes towards native speakers of different native languages differ, depending on the status and prestige attached to certain ethnic backgrounds. In that sense, Jaspers (2009:19) argues that two types of multilingualism can be distinguished, which he calls "prestigious" and "plebeian" multilingualism. As our study included only Chineseaccented speech samples, we cannot generalize our results to include all non-native speakers and it is possible that speech samples of speakers with different native languages (e.g. French or Arabic) would have yielded different results.

The study has implications for language teaching and assessment of language proficiency. Specifically, the relationship between attitudes and comprehensibility and accentedness judgements is interesting in light of second language testing procedures, in which speaking proficiency is assessed through scales using "intelligibility", "comprehensibility" and "accentedness" as central concepts. Given the currentcentrality of these concepts in language assessment, it is crucial to realize that judgements may be importantly influenced by the listener's or test taker's social attitudes. Test takers should be aware of the potential effects of their personal stance towards non-native speakers and their speech on the extent to which non-native speaking students are considered to be comprehensible and their speech accented. While such biases cannot be altogether ruled out, awareness of their possible presence may help to mitigate the effect. For that reason, it would be beneficial to include awareness raising of the effects of listeners' backgrounds and social attitudes in teacher training programmes.

Finally, further research on intelligibility is needed, using longer stretches of contextualized speech to be presented to listeners or looking at intelligibility and comprehensibility ratings in real interactions between native and non-native speakers. As noted above, intelligibility was assessed through a transcription task involving isolated words and nonwords and comprehensibility and accentedness ratings were based on relatively short stretches of speech. Future studies in which participants interact with each other in tasks would help us to understand whether listeners' social attitudes towards non-native speakers and their speech can also be linked to comprehensibility and accentedness judgements when real interaction with non-native speakers takes place.

\section{Acknowledgements}

We are grateful to Justine De Jaeger and Merel Beeckman for their help in collecting the data for this study. 


\section{References}

Babel, M. \& Russell, J. (2015) Expectations and speech intelligibility. Journal of the Acoustical Society of America, 137(5), 2823-2833.

Beinhoff, B. (2014) Perceiving intelligibility and accentedness in non-native speech: a look at proficiency levels. Concordia Working Papers in Applied Linguistics, 5, 58-72.

Bent, T. \& Bradlow, A.R. (2003) The interlanguage speech intelligibility benefit. Journal of the Acoustical Society of America, 114, 1600-1610.

Best, C.T. (1995) A Direct Realist View of Cross-Language Speech Perception. In W. Strange (ed) Speech Perception and linguistic experience: Issues in cross-language research. (pp.171-204). Timonium, MD: York Press.

Best, C.T. \& Tyler, M.D. (2007) Non-native and second-language speech perception: Commonalities and complementarities. In M.J. Munro \& O.-S. Bohn (eds) Second language speech learning: The role of language experience in speech perception and production. (pp. 13-34). Amsterdam: John Benjamins.

Bohn, O.S. \& Munro, M.J. (eds) (2007) Language experience in second language speech learning: In honor of James Emil Flege. Amsterdam: John Benjamins.

Bongaerts, T., Mennen, S. \& van der Slik, F. (2000) Authenticity of pronunciation in naturalistic second language acquisition: The case of very advanced late learners of Dutch as a Second Language. Studia Linguistica, 54(2), 298-308.

Burda, A.N., Casey, A.M., Foster, T.R., Pilkingston, A.K. \& Reppe, E.A. (2006) Effects of accent and age on the transcription of medically related utterances: A pilot study. Communications Disorders Quarterly, 27, 110-116.

Butkus, M., Maciulyte-Sniukiene, A. \& Matuzeviciute, K. (2016) Sociodemographic factors influencing attitude towards refugees: An analysis of data from European social survey, $16^{\text {th }}$ International Scientific Conference on Globalization and its Socio-Economic Consequences, University of Zilina, $5^{\text {th }}-6^{\text {th }}$ October 2016, 286-294.

Card, D., Dustmann, C. \& Preston, I. (2005) Understanding attitudes towards immigration: the migration and minority module of the European Social Survey, Discussion Paper Series No. 03/05, Centre for Research and Analysis of Migration, University College London, available at https://discovery.ucl.ac.uk/id/ eprint/14315/1/14315.pdf., last accessed 26.5.2021.

Caspers, J. \& Horloza, K. (2012) Intelligibility of non-native produced Dutch words: Interaction between segmental and suprasegmental errors. Phonetica, 69, 94107. 
Chandler, C.R. \& Tsai, Y. (2001) Social factors influencing immigration attitudes. The Social Science Journal 38, 177-188.

Council of Europe. (2001) Common European framework of reference for languages: Learning, teaching, assessment. Cambridge, U.K: Press Syndicate of the University of Cambridge.

Davies, A. (2013) Native speakers and native users: loss and gain. Cambridge: Cambridge University Press.

Delarue, S. (2016) Bridging the policy-practice gap: How Flemish teachers' standard language perceptions navigate between monovarietal policy and multivarietal practice. Unpublished Doctoral dissertation. Linguistics Department, Ghent University.

Derwing, T.M. \& Munro, M.J. (1997) Accent, intelligibility and comprehensibility: Evidence from four L1s. Studies in Second Language Acquisition, 19(1), 1-16.

Deschouwer, K., Delwit, P., Hooghe, M. \& Walgrave, S. (eds) (2010) Les Voix du Peuple. Brussels: Editions de l'Université de Bruxelles.

Eisenstein, M. \& Verdi, G. (1985) The intelligibility of social dialects for workingclass adult learners of English. Language Learning, 35(2), 287-298.

Flege, J.E. (1995) Second-language speech learning: Theory, findings, and problems. In W. Strange (ed.) Speech Perception and linguistic experience: Issues in crosslanguage research. (pp. 229-273). Timonium, MD: York Press.

. (2005) Misinterpretation, bias and resistance to change: The case of the Lingua Franca Core. In K. Dziubalska \& J. Przedlacka (eds) English Pronunciation Models: A changing scene. (pp. 199-212). Bern: Peter Lang

Gallardo del Puerto, F., García Lecumberri, M. \& Gómez Lacabex, E. (2015) The assessment of foreign accent and its communicative effects by naïve native judges vs. experienced non-native judges. International Journal of Applied Linguistics, 25(3), 202-224.

Grondelaers, S. \& Speelman, D. (2013) Can speaker evaluation return private attitudes towards stigmatised varieties? Evidence from emergent standardisation in Belgian Dutch. In T. Kristiansen \& S. Grondelaers (Eds.), Language (de)standardisation in Late Modern Europe: experimental studies. Oslo: Novus Forlag, 171-191.

Grondelaers, S. \& van Gent, P. (2019) How “deep” is Dynamism? Revisiting the evaluation of Moroccan-flavored Netherlandic Dutch. Linguistics Vanguard, 5(1).

Hainmueller, J. \& Hiscox, M.J. (2007) Educated preferences: Explaining attitudes towards immigration in Europe. International Organization, 61(2), 399-442.

Hayes-Harb, R., Smith, B.L., Bent, T. \& Bradlow, A.R. (2008) The interlanguage speech intelligibility benefit for native speakers of Mandarin: Production and perception of English word-final voicing contrasts. Journal of Phonetics, 36(4), 664-679. 
Hooghe, M., Meeusen, C. \& Quintelier, E. (2013) The impact of education and intergroup friendship on the development of ethnocentrism. A latent growth curve model analysis of a five-year panel study among Belgian late adolescents. European Sociological Review, 29(6), 1109-1121.

Jaspers, J. (2009) De klank van de stad: stedelijke meertaligheid en interculturele communicatie. Leuven: Acco.

Jenkins, J. (2000) The Phonology of English as an International Language. Oxford: Oxford University Press.

Kachru, Y. \& Smith, L.E. (2008) Cultures, Contexts, and World Englishes. New York: Routledge.

Kang, O., Thompson, R.I. \& Moran, M. (2018) Empirical Approaches to Measuring the Intelligibility of Different Varieties of English in Predicting Listener Comprehension. Language Learning, 68 (1), 115-146.

Kennedy, S. \& Trofimovich, P. (2019) Comprehensibility: A useful tool to explore listener understanding. The Canadian Modern Language Review / La revue canadienne des langues vivantes, 75(4), 275-284.

Kent, D.R. \& Miolo, G. (1994) The intelligibility of children's speech. American Journal of Speech-Language Pathology, 3, 81-95.

Latour, B., Van Hout, R. \& Grondelaers, S. (2012) De schoonheid van taal. Hoe wezenlijk is het oordeel mooi in taalattitudes? Taal en Tongval, 64(2), 243-261.

Levis, J. \& LeVelle, K. (eds) (2010) Pronunciation and intelligibility: Issues in research and practice, Proceedings of the $2^{\text {nd }}$ Annual Pronunciation in Language Learning and Teaching Conference, 10-11 September 2010, Iowa State University.

Lindeman, S. (2002) Listening with an attitude: a model of native-speaker comprehension of non-native speakers in the United States. Language in Society, 31, 419-441.

Lybaert, C. (2017) A direct discourse-based approach to the study of language attitudes: The case of tussentaal in Flanders. Language Sciences, 59, 93-116.

Major, R. (2001) Foreign Accent: The Ontogeny and Phylogeny of Non-Native Speech. New Jersey/London: Lawrence Erlbaum Associates.

Mattys, S.L., Davis, M.H., Bradlow, A.R. \& Scot, S.K. (2012) Speech recognition in adverse conditions: A review. Language $\mathcal{E}$ Cognitive processes, 27, 953-978.

Mayda, A.M. (2006) Who is against immigration? A cross-country investigation of individual attitudes towards immigrants. Review of Economics and Statistics, 88(3), 510-530. 
Morley, J. (1991) The pronunciation component in teaching English to speakers of other languages, TESOL Quarterly, 25, 481-520.

Munro, M.J. (2008) Foreign accent and speech intelligibility. In H. Edwards, J.G. \& M.L. Zampini (eds) Phonology and Second Language Acquisition. (pp. 193-218) Amsterdam: John Benjamins.

Munro, M.J. \& T.M. Derwing. (1995a) Foreign accent, comprehensibility, and intelligibility in the speech of second language learners. Language Learning, 45, 73-97. . (1995b) Processing time, accent, and comprehensibility in the perception of foreign-accented speech. Language and Speech, 38, 289-306.

Murray, K.E. \& Marx, D.M. (2013) Attitudes toward unauthorized immigrants, authorized immigrants and refugees. Cultural Diversity and Ethnic Minority Psychology, 19(3), 332-341.

Noppe, J., Vanweddingen, M., Doyen, G., Stuyck, K., Feys, S. \& Buysschaert, P. (2018) Vlaamse Migratie- en Integratiemonitor 2018. Brussel: Agentschap Binnenlands Bestuur (available at https://www.statistiekvlaanderen.be/nl/vlaamse-migratie-enintegratiemonitor, accessed on 26.5.2021).

Rajadurai, J. (2007) Intelligiblity studies: a consideration of empirical and ideological issues, in Forum: Ideology and intelligibility. World Englishes, 26(1), 87-98.

Rubin, D.M. (1992) Nonlanguage factors affecting undergraduates' judgements of non-native English-speaking teaching assistants. International Journal of Intercultural Relations, 14(3), 337-353.

Saito, K., Trofimovich, P. \& Isaacs, T. (2017) Using listener judgements to investigate linguistic influences on L2 comprehensibility and accentedness: A validation and generalization study. Applied Linguistics, 38(4), 439-462.

Saito, K., Tran, M., Suzukida, Y., Sun, H., Magne, V. \& Ilkan, M. (2019) How do second language listeners perceive the comprehensibility of foreign-accented speech? Roles of L1 profiles, L2 proficiency, age, experience, familiarity and metacognition. Studies in Second Language Acquisition, 41(5), 1133-1149.

Semyonov, M., Raijman, R. \& Gorodzeisky, A. (2006) The rise of anti-foreigner sentiment in European societies, 1988-2000. American Sociological Review, 71(3), 426-449.

Sheppard, B.E., Elliott, N.C. \& Baese-Berk, M.M. (2017) Comprehensibility and intelligibility of international student speech: Comparing perceptions of university EAP instructors and content faculty. Journal of English for Academic Purposes, 26, 42-51.

Taylor Reid, K., Trofimovich, P. \& O’Brien, M.G. (2019) Social attitudes and speech ratings. Effects of positive and negative bias on multiage listeners' judgments of second language speech. Studies in Second Language Acquisition, 41, 419-442. 
Winke, P., Gass, S. \& Myford, C. (2013) Raters' L2 background as a potential source of bias in rating oral performance. Language Testing, 30(2), 231-252.

\section{Appendices}

Appendix 1: Semantically meaningful and nonsensical sentences

\begin{tabular}{|c|c|c|}
\hline & $\begin{array}{l}\text { Dutch sentence } \\
\text { (omitted word in bold) }\end{array}$ & English translation \\
\hline \multicolumn{3}{|c|}{ Semantically meaningful sentences } \\
\hline \multirow[t]{2}{*}{$\begin{array}{l}\text { Test } \\
\text { sentences }\end{array}$} & Mijn kleine zus ziet er goed uit. & My little sister is looking good. \\
\hline & $\begin{array}{l}\text { De lieve prinses heeft een lange } \\
\text { vlecht. }\end{array}$ & $\begin{array}{l}\text { The sweet princess has a long } \\
\text { plait. }\end{array}$ \\
\hline \multirow[t]{6}{*}{ Speaker 1} & $\begin{array}{l}\text { De nieuwe koper biedt een mooi } \\
\text { bedrag. }\end{array}$ & $\begin{array}{l}\text { The new buyer offers a good } \\
\text { price. }\end{array}$ \\
\hline & De oude man bidt in de kerk. & $\begin{array}{l}\text { The old man is praying in } \\
\text { church. }\end{array}$ \\
\hline & Mijn rode step gaat toch wat snel. & My red scooter goes a little fast. \\
\hline & De groene peer ligt in die mand. & The green pear is in that basket. \\
\hline & De grijze rat kruipt in het hol. & $\begin{array}{l}\text { The grey rat is crawling into the } \\
\text { hole. }\end{array}$ \\
\hline & Die wijze raad vergeet hij nooit meer. & $\begin{array}{l}\text { This wise piece of advice he'll } \\
\text { never forget. }\end{array}$ \\
\hline \multirow[t]{5}{*}{ Speaker 2} & De kwade stier kijkt naar de lap. & $\begin{array}{l}\text { The angry bull is looking at the } \\
\text { rag. }\end{array}$ \\
\hline & Het witte schip vaart naar de zee. & $\begin{array}{l}\text { The white ship is sailing to the } \\
\text { sea. }\end{array}$ \\
\hline & $\begin{array}{l}\text { De stoute jongen vecht met zijn } \\
\text { broer. }\end{array}$ & $\begin{array}{l}\text { The naughty boy is fighting with } \\
\text { his brother. }\end{array}$ \\
\hline & $\begin{array}{l}\text { De boze vrouw veegt met haar } \\
\text { bezem. }\end{array}$ & $\begin{array}{l}\text { The angry woman is sweeping } \\
\text { with her broom. }\end{array}$ \\
\hline & De sterke boer kapt met een bijl. & $\begin{array}{l}\text { The strong farmer is hacking with } \\
\text { an axe. }\end{array}$ \\
\hline
\end{tabular}




\begin{tabular}{|c|c|c|}
\hline & De snelle loper kaapt de prijs weg. & $\begin{array}{l}\text { The fast runner takes away the } \\
\text { prize. }\end{array}$ \\
\hline \multicolumn{3}{|c|}{ Nonsensical sentences } \\
\hline \multirow[t]{2}{*}{$\begin{array}{l}\text { Test } \\
\text { sentences }\end{array}$} & De zachte broek bidt op het bad. & $\begin{array}{l}\text { The soft trousers are praying on } \\
\text { the bath. }\end{array}$ \\
\hline & $\begin{array}{l}\text { De slimme zak voelt naar meer } \\
\text { graan. }\end{array}$ & $\begin{array}{l}\text { The clever bag feels after more } \\
\text { grain. }\end{array}$ \\
\hline \multirow[t]{6}{*}{ Speaker 1} & Mijn witte boek piekt naar de zee. & $\begin{array}{l}\text { My white book is peaking into } \\
\text { the sea. }\end{array}$ \\
\hline & De zware jas pikt op zijn rug. & $\begin{array}{l}\text { The black coat is pecking on his } \\
\text { back. }\end{array}$ \\
\hline & De kleine rand heft onder het zand. & $\begin{array}{l}\text { The small edge lifts under the } \\
\text { sand. }\end{array}$ \\
\hline & $\begin{array}{l}\text { Die kleine koek heeft veel dure } \\
\text { spullen. }\end{array}$ & $\begin{array}{l}\text { That small biscuit has much } \\
\text { expensive stuff. }\end{array}$ \\
\hline & De sterke kaas heeft met een bijl. & $\begin{array}{l}\text { That strong cheese has with an } \\
\text { axe. }\end{array}$ \\
\hline & De snelle kat kijkt de prijs weg. & $\begin{array}{l}\text { That quick cat looks away the } \\
\text { prize. }\end{array}$ \\
\hline \multirow[t]{6}{*}{ Speaker 2} & De rode baas ziet toch wat snel. & The red boss looks a little quick. \\
\hline & De groene reus zit in die mand. & $\begin{array}{l}\text { The green giant is sitting in that } \\
\text { basket. }\end{array}$ \\
\hline & De oude zeep zoekt in de kerk. & $\begin{array}{l}\text { The old soap is searching in the } \\
\text { church. }\end{array}$ \\
\hline & Zijn grote schep prijst het hooi op. & $\begin{array}{l}\text { His large shovel is praising the } \\
\text { hay. }\end{array}$ \\
\hline & De lieve zaak plakt een lange vlecht. & $\begin{array}{l}\text { The sweet case is sticking a long } \\
\text { plait. }\end{array}$ \\
\hline & $\begin{array}{l}\text { De slimme zak voelt naar meer } \\
\text { graan. }\end{array}$ & $\begin{array}{l}\text { The clever bag feels for more } \\
\text { grain. }\end{array}$ \\
\hline
\end{tabular}


Appendix 2: Comprehensibility and accentedness judgment task: semi-spontaneous speech

\section{Speaker 1:}

"Mijn droomreis is zeker Japan. Ik wil heel graag [euh] met mijn man gaan. [euh] Japan is een van de weinig land ter wereld met combinatie van [euh] cultuur traditie maar ook modern aspect." (18 seconds)

\section{Speaker 2:}

"[Euh] wij hebben 4 dagen euh lessen genomen [euh] met één instructor van de duikencenter [euh] en wij hebben veel [euh] vissen en dieren gezien in de zee. Ik ben echt [euh] heel blij dat [euh] ik daar kan zijn." (21 seconds)

\section{Appendix 3: Speaker/speech evaluation task: read speech}

In Parijs staat een nieuw kunstwerk. De Amerikaanse kunstenaar maakt een grote hand die tulpen vasthoudt. Daarmee wil hij de slachtoffers eren van de aanslagen op 13 november 2015. Toen stierven er in Parijs 130 mensen. (24 seconds for speaker 1; 22 seconds for speaker 2) 